Keywords: Tank Farm Characterization

Salt Dissolution

Low Curie Salt

Retention: Permanent

\title{
Tank 38H Saltcake Core and Supernate Sample Analysis
}

\author{
C. J. Martino \\ R. L. Nichols \\ D. J. McCabe \\ E. K. Hansen
}

Publication date: April 8, 2004

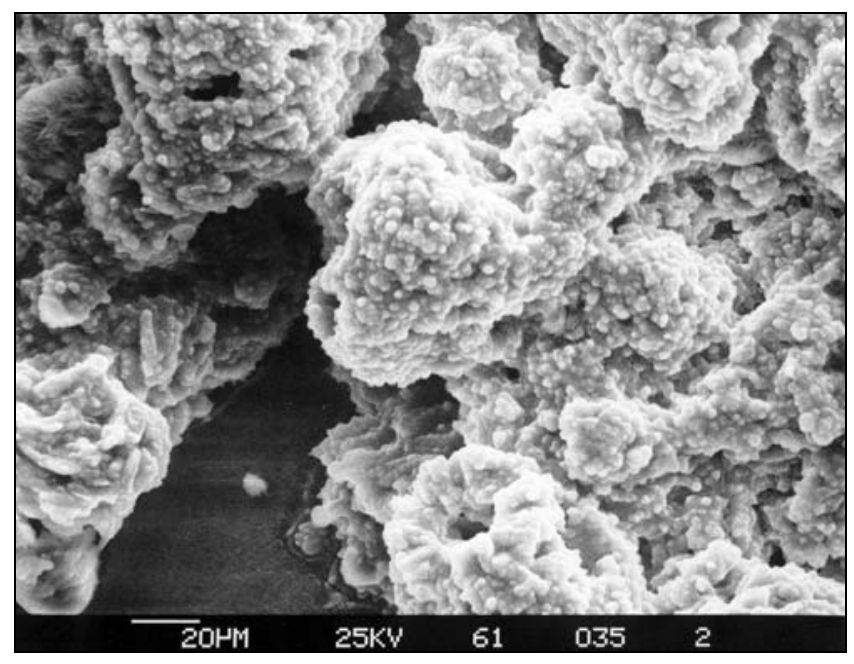

Westinghouse

Savannah River Company

Aiken, SC 29808 
This document was prepared in conjunction with work accomplished under Contract No. DE-AC09-96SR18500 with the U. S. Department of Energy.

\section{DISCLAIMER}

This report was prepared as an account of work sponsored by an agency of the United States Government. Neither the United States Government nor any agency thereof, nor any of their employees, makes any warranty, express or implied, or assumes any legal liability or responsibility for the accuracy, completeness, or usefulness of any information, apparatus, product or process disclosed, or represents that its use would not infringe privately owned rights. Reference herein to any specific commercial product, process or service by trade name, trademark, manufacturer, or otherwise does not necessarily constitute or imply its endorsement, recommendation, or favoring by the United States Government or any agency thereof. The views and opinions of authors expressed herein do not necessarily state or reflect those of the United States Government or any agency thereof.

This report has been reproduced directly from the best available copy.

Available for sale to the public, in paper, from: U.S. Department of Commerce, National Technical Information Service, 5285 Port Royal Road, Springfield, VA 22161, phone: (800) 553-6847, fax: (703) 605-6900

email: orders@ntis.fedworld.gov

online ordering: http://www.ntis.gov/help/index.asp

Available electronically at http://www.osti.gov/bridge

Available for a processing fee to U.S. Department of Energy and its contractors, in paper, from: U.S. Department of Energy, Office of Scientific and Technical Information, P.O. Box 62, Oak Ridge, TN 37831-0062,

phone: (865)576-8401,

fax: (865)576-5728

email: $\underline{\text { reports@ adonis.osti.gov }}$ 
WSRC-TR-2004-00129

Revision 0

\section{Summary}

This report provides details of the characterization of Tank 38H saltcake (HTF-E-03-114) and supernate (HTF-E-03-122 and 123) samples pulled in September 2003. The following are the major conclusions of this analysis:

- The core sample HTF-E-03-114 contained approximately 4 inches of saltcake, which was soupy and brown with white chunks, and contained less than $15 \mathrm{~mL}$ of cloudy free liquid.

- The undrained bulk saltcake had a water content of $16.8 \mathrm{wt} \%$ and a bulk density that was approximately $1.94 \mathrm{~g} / \mathrm{cm}^{3}$ at full saturation.

- The ${ }^{137} \mathrm{Cs}$ activity of the bulk saltcake in sample HTF-E-03-114 was $3.72 \mathrm{E}+7 \mathrm{pCi} / \mathrm{g}$, which corresponds to $0.3 \mathrm{Ci}$ per gallon of saltcake. The ${ }^{238} \mathrm{Pu}$ activity of the bulk saltcake was $3.62 \mathrm{E}+6 \mathrm{pCi} / \mathrm{g}$.

- The filtered free liquid in sample HTF-E-03-114 had a density of $1.430 \mathrm{~g} / \mathrm{cm}^{3}, a^{137} \mathrm{Cs}$ activity of $0.73 \mathrm{Ci} / \mathrm{gal}$., and $\mathrm{a}^{238} \mathrm{Pu}$ activity of $5.78 \mathrm{E}+3 \mathrm{pCi} / \mathrm{mL}$

- The solids filtered from the HTF-E-03-114 free liquid were primarily composed of salts (sodium nitrate and sodium carbonate monohydrate) and sodium aluminosilicates.

- The Tank $38 \mathrm{H}$ supernate samples (HTF-E-03-122 and 123) had a density of $1.45 \mathrm{~g} / \mathrm{cm}^{3}$, a ${ }^{137} \mathrm{Cs}$ activity of $0.65 \mathrm{Ci} / \mathrm{gal}$, a ${ }^{238} \mathrm{Pu}$ activity of $2.2 \mathrm{E} 4 \mathrm{pCi} / \mathrm{mL}$, and contained no visible insoluble solids.

- The viscosity of supernate samples HTF-E-03-122 and 123 was determined at $25^{\circ} \mathrm{C}, 35^{\circ} \mathrm{C}$, and $50^{\circ} \mathrm{C}$ to be $12.1 \mathrm{cP}, 8.1 \mathrm{cP}$, and $5.1 \mathrm{cP}$, respectively. An exponential correlation for the Tank $38 \mathrm{H}$ supernate viscosity was formulated for use over this temperature range.

- In the undrained saltcake sample, several components, including cesium, nitrite, hydroxide, phosphate, formate, and potassium, were partitioned predominantly into the interstitial liquid .

- Although the plutonium, uranium, neptunium, and strontium activities in the Tank $38 \mathrm{H}$ saltcake core sample are high compared with recent Tank $41 \mathrm{H}$ samples, they are low compared with previous saltcake samples from Tank $38 \mathrm{H}$ collected in July 2000 and July 2001.

- The ${ }^{137} \mathrm{Cs}$ of the Tank $38 \mathrm{H}$ saltcake sample is comparable with the previous Tank $38 \mathrm{H}$ saltcake samples. 
This page was intentionally left blank 


\section{Table of Contents}

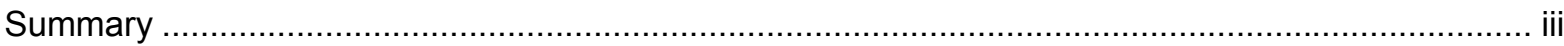

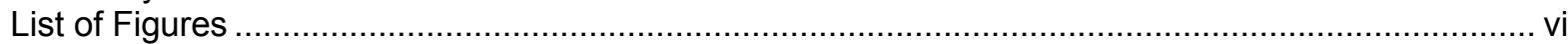

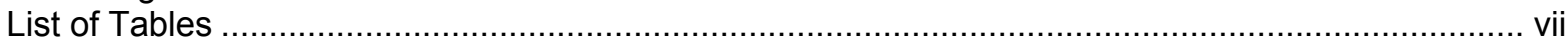

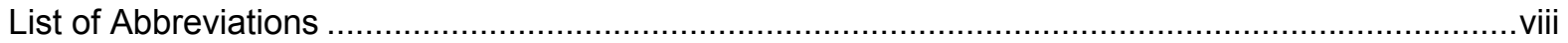

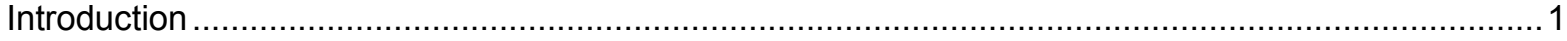

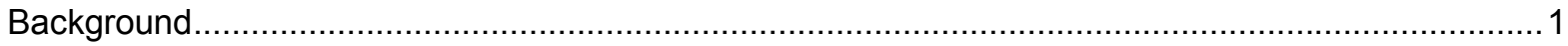

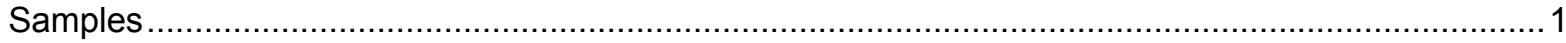

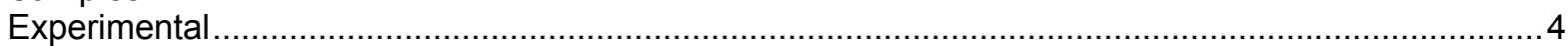

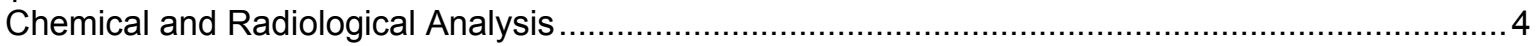

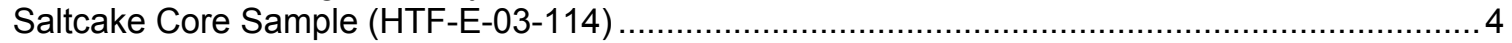

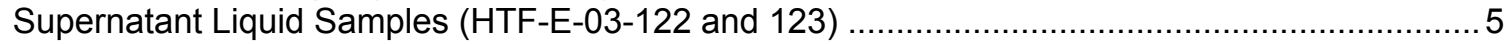

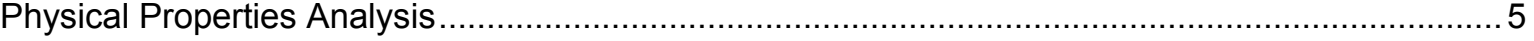

Density, Moisture, and Percent Interstitial Liquid ................................................................. 5

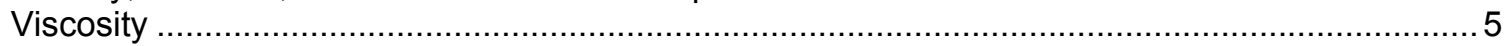

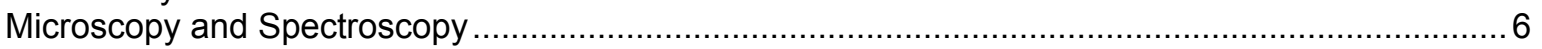

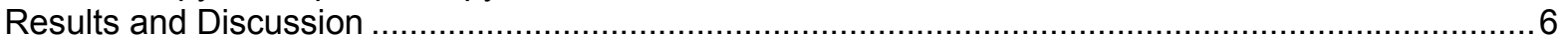

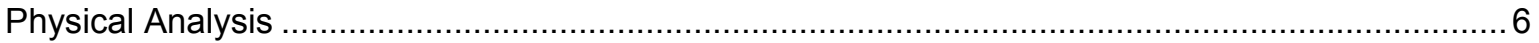

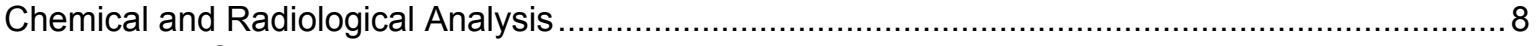

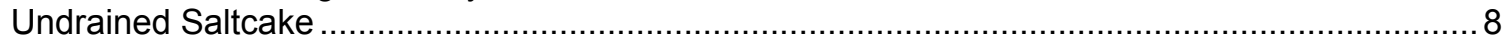

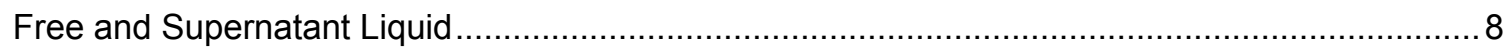

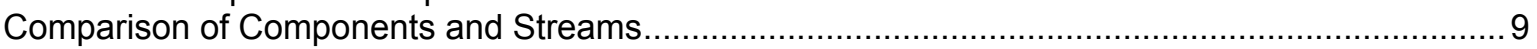

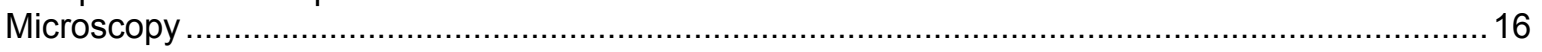

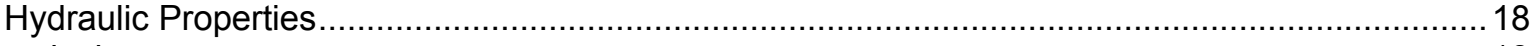

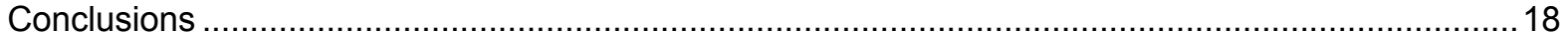

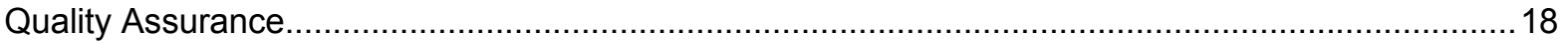

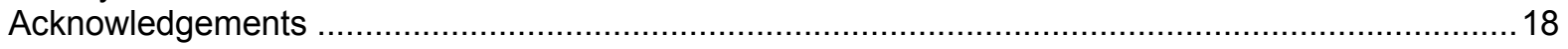

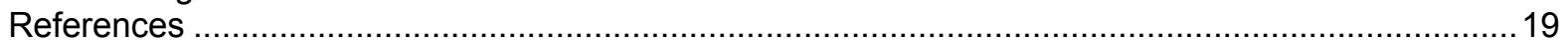

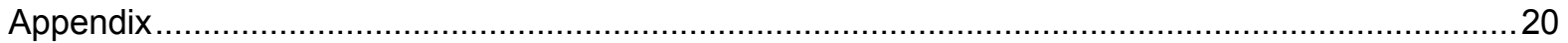


WSRC-TR-2004-00129

Revision 0

\section{List of Figures}

Cover Photo: SEM of insoluble solids, which likely are cancrinite, filtered from the Tank $38 \mathrm{H}$ sample free liquid.

Figure 1: Material contained in Tank 38H core sample .......................................................... 2

Figure 2: Deformed bottom lip of HTF-E-03-114, received with cutting head attached ..................... 2

Figure 3: Material removed from the Tank $38 \mathrm{H}$ saltcake core sample (HTF-E-03-114) .................... 3

Figure 4: Free Liquid decanted from HTF-E-03-114, unfiltered and filtered .................................... 3

Figure 5: Tank 38H supernate samples HTF-E-03-122 and 123, as received (unfiltered).................. 4

Figure 6: Viscosity of the Tank 38H Supernate Samples HTF-E-03-122 and 123 Composite............. 8

Figure 7: Likely major components of Tank $38 \mathrm{H}$ salt solids, normalized to $100 \mathrm{wt}$. \%.................... 14

Figure 8: XRD of insoluble solids filtered from the free liquid contained in the Tank $38 \mathrm{H}$ saltcake

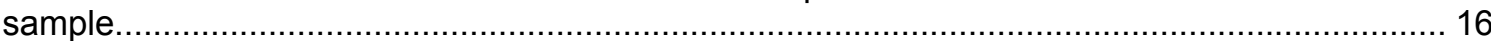

Figure 9: SEM images of insoluble solids filtered from the free liquid contained in the Tank $38 \mathrm{H}$

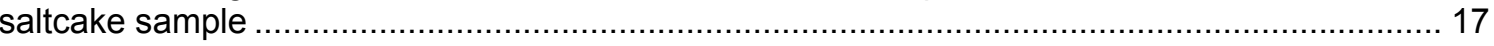

Figure 10: SEM and EDS of needle-like insoluble solids from the filtered free liquid of sample HTF-E-

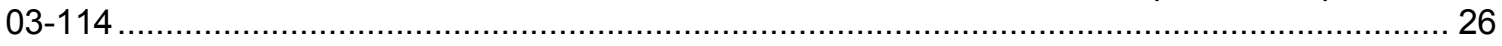

Figure 11: SEM and EDS of insoluble solids from the filtered free liquid of sample HTF-E-03-114 .. 27 Figure 12: SEM and EDS of globular porous insoluble solids from the filtered free liquid of sample HTF-E-03-114 


\section{List of Tables}

Table 1: Summary of physical aspects of the Tank $38 \mathrm{H}$ samples 7

Table 2: Summary of radioactive components in Tank $38 \mathrm{H}$ samples .........................................11

Table 3: Summary of ionic components in Tank $38 \mathrm{H}$ samples .............................................. 12

Table 4: Summary of other elemental components in Tank 38H samples................................... 13

Table 5: Comparison of components in Tank 38H liquids, including direct measurement of filtered free liquid (FL) and supernatant liquid (SL), and projections for dissolved salts (containing residual insoluble solids) from undrained (UDS) and drained (DDS) saltcake ...

Table 6: Comparison of HTF-E-03-114 with previous Tank $38 \mathrm{H}$ saltcake surface samples................ 15

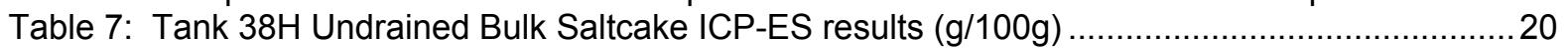

Table 8: Tank 38H Undrained Bulk Saltcake rad. chem. results (pCi/g) ...................................... 21

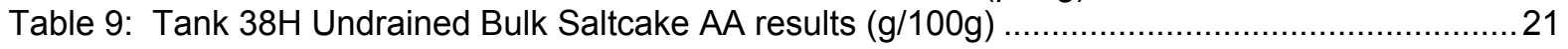

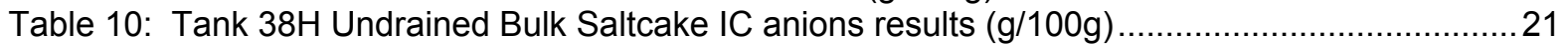

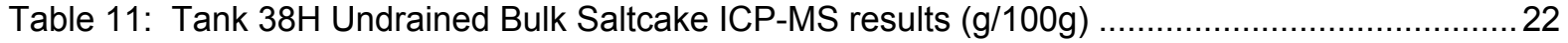

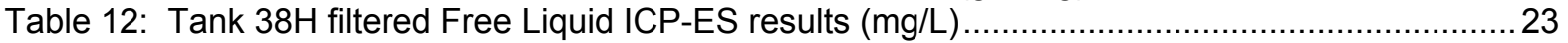

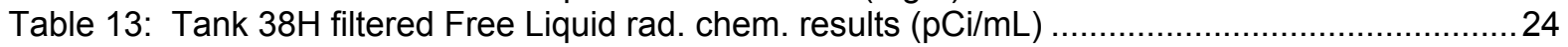

Table 14: Tank 38H filtered Free Liquid ICP-MS results (mg/L) ............................................. 24

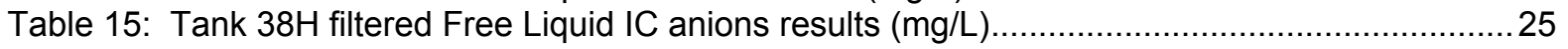

Table 16: Likely major components of Tank $38 \mathrm{H}$ salt solids, normalized to $100 \mathrm{wt}$. \% ....................25

Table 17: Tank $38 \mathrm{H}$ supernate sample (HTF-E-03-122 and 123) rad. chem. results $(\mathrm{pCi} / \mathrm{mL}) \ldots \ldots \ldots . .29$

Table 18: Tank $38 \mathrm{H}$ supernate sample (HTF-E-03-122 and 123) IC anions, wet chemistry titration,

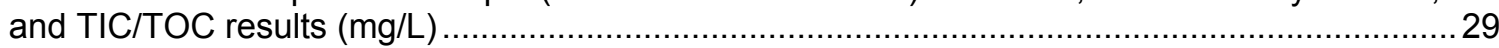

Table 19: Tank 38H supernate sample (HTF-E-03-122 and 123) ICP-ES results (mg/L) ...................30

Table 20: Tank 38H supernate sample (HTF-E-03-122 and 123) ICP-MS results (mg/L).................31

Table 21: Tank 38H supernate sample (HTF-E-03-122 and 123) AA results (mg/L)........................ 31 
WSRC-TR-2004-00129

Revision 0

\section{List of Abbreviations}

$\begin{array}{ll}\text { AA } & \text { Atomic Absorption spectroscopy } \\ \text { ADS } & \text { Analytical Development Section } \\ \text { DDS } & \text { Drained Dissolved Salt } \\ \text { DI } & \text { de-ionized } \\ \text { DWPF } & \text { Defense Waste Processing Facility } \\ \text { EDS } & \text { X-ray Emission Dispersive Spectroscopy } \\ \text { FL } & \text { Free Liquid supernatant to a saltcake sample upon receipt } \\ \text { IC } & \text { lon Chromatography } \\ \text { ICP-ES } & \text { Inductively-Coupled Plasma - Emission Spectroscopy } \\ \text { ICP-MS } & \text { Inductively-Coupled Plasma - Mass Spectroscopy } \\ \text { I.D. } & \text { inner diameter } \\ \text { IL } & \text { Interstitial Liquid drained from a saltcake sample } \\ \text { LCS } & \text { Low-Curie Salt } \\ \text { LWD } & \text { Liquid Waste Disposition } \\ \text { N/A } & \text { Not Applicable } \\ \text { O.D. } & \text { outer diameter } \\ \text { PIL } & \text { Partition into Interstitial Liquid } \\ \text { SEM } & \text { Scanning Electron Microscopy } \\ \text { SL } & \text { Supernatant Liquid from a tank supernate sample } \\ \text { SPF } & \text { Saltstone Processing Facility } \\ \text { SRS } & \text { Savannah River Site } \\ \text { SRTC } & \text { Savannah River Technology Center } \\ \text { TIC } & \text { Total Inorganic Carbon } \\ \text { TOC } & \text { Total Organic Carbon } \\ \text { UDS } & \text { Un-drained Dissolved Salt } \\ \text { WCS } & \text { Waste Characterization System } \\ \text { XRD } & \text { X-Ray Diffraction spectroscopy } \\ \end{array}$




\section{Introduction}

In support of Low-Curie Salt (LCS) process validation, Liquid Waste Disposition (LWD) has undertaken a program of tank characterization, including salt sampling. ${ }^{1,2}$ As part of this initiative, in September, 2003, they sampled the surface of the Tank $38 \mathrm{H}$ saltcake using a $\sim 12$-inch long sample tube (HTF-E-03-114). The primary objective of the characterization is to gather information that will be useful to the selection and processing of the next salt waste tanks. To confirm that Tank $38 \mathrm{H}$ is acceptable for salt processing, the ${ }^{137} \mathrm{Cs}$ concentration and liquid retention properties of the saltcake must be determined. Chemical analyses are performed to provide information on salt elemental, ionic, and radiological components to aid in assessing the composition of the salt after dissolution. This report also includes results for supernate samples (HTF-E-03-122 and 123) that were collected from Tank $38 \mathrm{H}$ at nearly the same time as the saltcake.

\section{Background}

The majority of the current saltcake inventory in Tank 38H was created from 1981 until the mid 1990's by evaporation of low-heat waste in the $242-16 \mathrm{H}(2 \mathrm{H})$ evaporator. Starting in 1996 and continuing to the present time, neutralized Defense Waste Processing Facility (DWPF) recycle has been sent to Tank $43 \mathrm{H}$ and concentrated in the $2 \mathrm{H}$-evaporator system. Tank $38 \mathrm{H}$, as the drop tank for the $2 \mathrm{H}$ evaporator, has been receiving concentrated DWPF recycle. Since the composition of this material is different from typical concentrated salt solution supernate, it has the potential to both dissolve a portion of the current saltcake and precipitate atypical species. Due to the presence of both aluminum and silicon in this system, sodium aluminosilicate phases have historically been formed during $2 \mathrm{H}$ evaporator operation. ${ }^{3}$

Several saltcake samples had previously been collected from Tank $38 \mathrm{H}$ and analyzed to gain information important to criticality safety. In 1996, a set of saltcake samples (HTF-003) were taken from the salt supernate interface of Tank $38 \mathrm{H}$ and the total saltcake and insoluble solids were characterized. ${ }^{4}$ A similar saltcake sample (HTF-093) was taken in 1998, but only the residual waterinsoluble solids were analyzed. ${ }^{5}$ In July 2000 , another set of saltcake samples (no tank farm identification numbers) were taken from Tank $38 \mathrm{H}$ and analyzed as-received. ${ }^{6}$. The sample was noted to consist of two types of solid material: small white pebbles and black sludge-like material. The chemical and radiological composition of both types of material were comparable. As part of the same study, two additional saltcake samples (HTF-395 and 396) were pulled from Tank $38 \mathrm{H}$ in January 2001, for use in insoluble solids analysis. A follow-up study, including only the analysis of the as-received saltcake material, was performed on a set of Tank $38 \mathrm{H}$ saltcake surface samples taken in July 2001 . $^{7}$

At the time of collecting these current Tank $38 \mathrm{H}$ supernate and saltcake core samples, the supernate surface was at 309 tank inches and the saltcake surface was at approximately 243 tank inches.

\section{Samples}

On September 11, 2003, LWD began a process to collect three salt core samples from riser $\mathrm{G}$ of Tank $38 \mathrm{H}$. The sampling procedure was interrupted, however, when the sample tube (0.95 in. I.D., 1.13 in. O.D., 13.7 in. long) could not be retrieved through the guide pipe. On September 21, one sample was removed from the tank. The sample was delivered to SRTC on September 22, placed in the shielded cells on September 23, and processed on September 25. The sample had a portion of the guide pipe and sample mast still attached.

Figure 1 displays the approximate contents of the Tank $38 \mathrm{H}$ sample. The sampling tube contained approximately 4 inches of salt and less than an inch of free liquid. Because the bottom of the sampler was deformed (see Figure 2), a shipping cap could not be fitted to the sampler in the field. Thus, to 
avoid leakage, the sample was shipped inverted (upside-down from the depiction shown in Figure 1). In order to place the sample in the shielded cells in a vertical orientation, the sample was to be brought in through the top of Cell 3. During opening of the primary shipping container, Shielded Cells Operations personnel noted strong ammonia-like odor. Thus, the entire primary shipping container was placed into the cell. Although it is unusual that free liquid would be beneath the solid, this is probably an anomaly of the way the sample was shipped. It is likely that the solid was at the bottom of the sampler during retrieval, and the liquid above it, but this reversed when the sample was inverted and shipped.
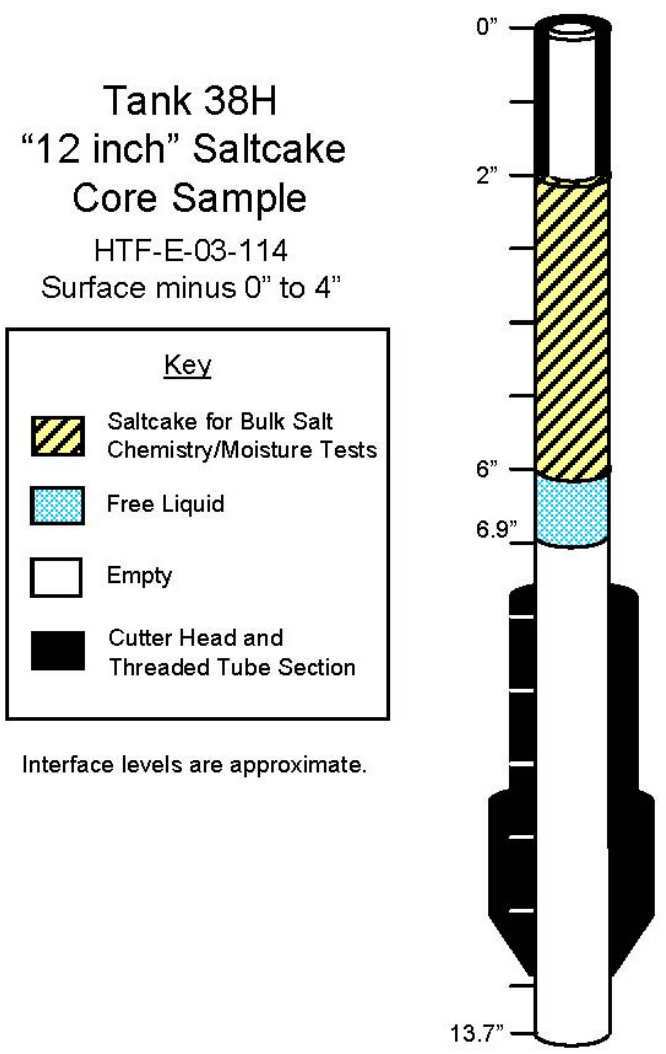

Figure 1: Material contained in Tank $38 \mathrm{H}$ core sample
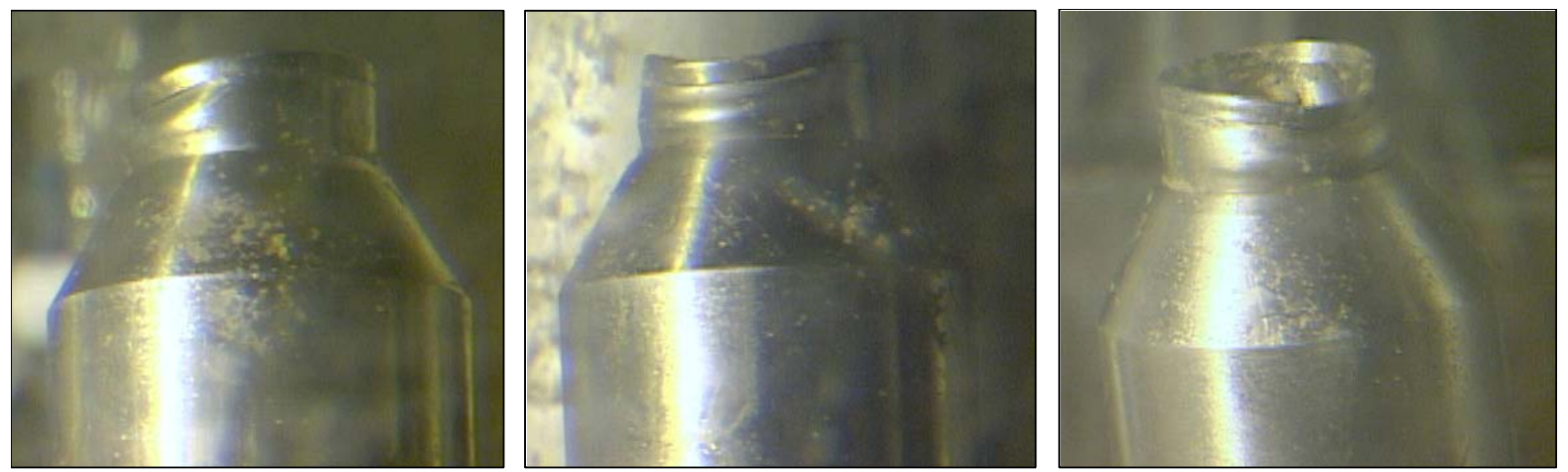

Figure 2: Deformed bottom lip of HTF-E-03-114, received with cutting head attached 

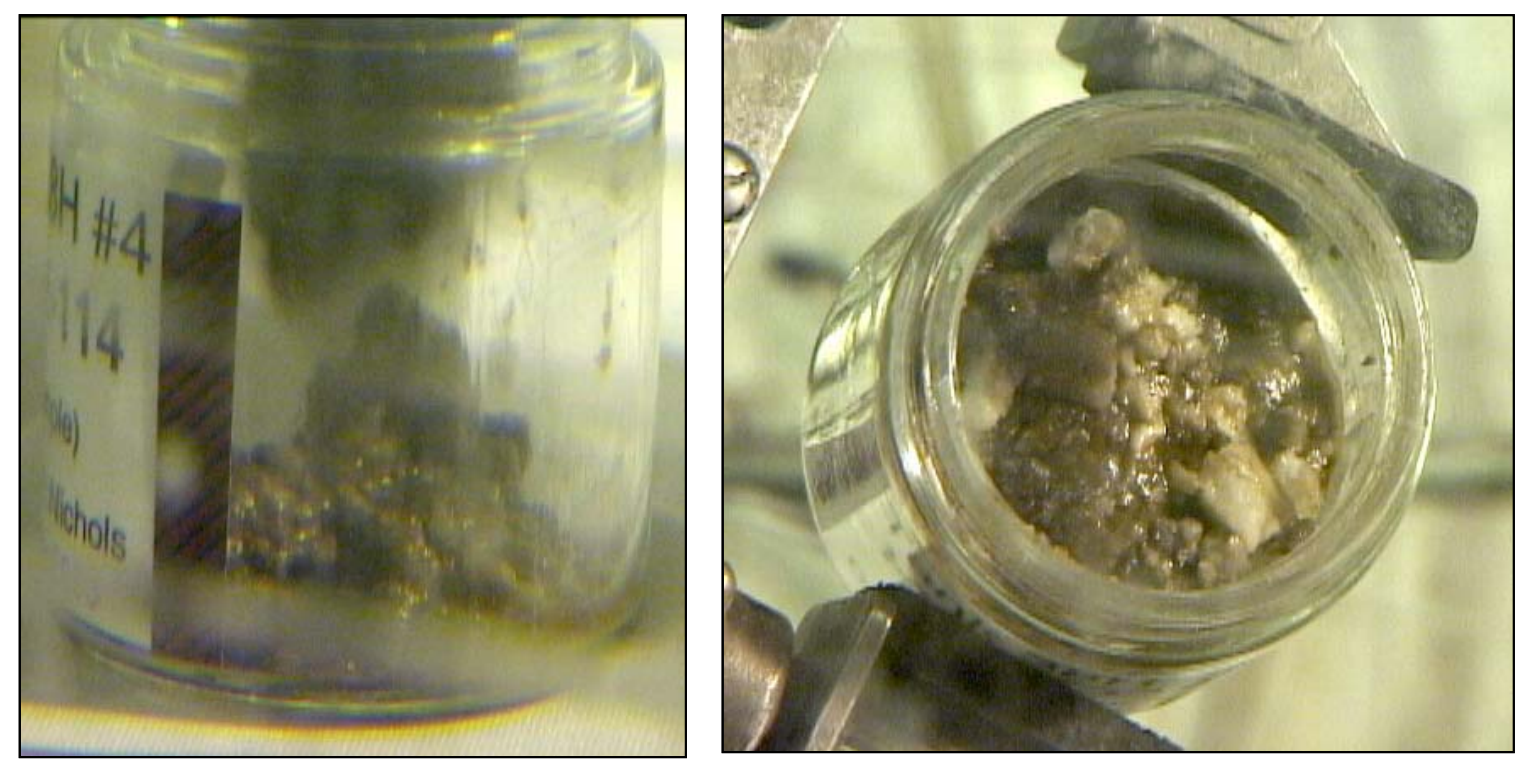

Figure 3: Material removed from the Tank 38H saltcake core sample (HTF-E-03-114)
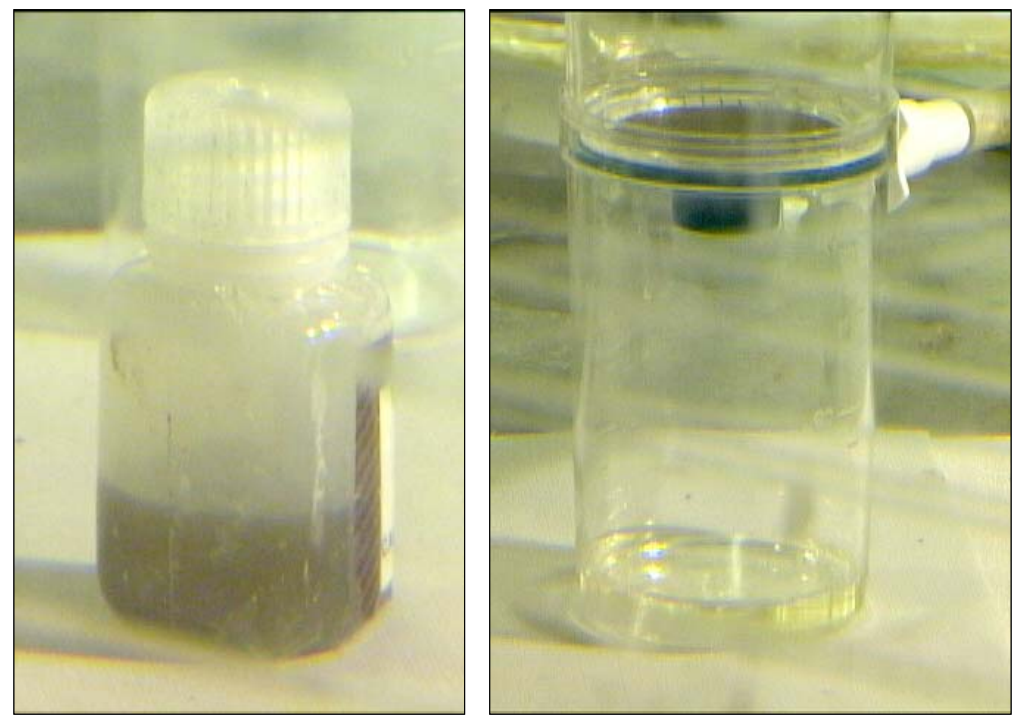

Figure 4: Free Liquid decanted from HTF-E-03-114, unfiltered and filtered

Figure 3 shows the salt that was removed from the sample tube. The saltcake was soupy and brown with light colored chunks, which is consistent with the description of the Tank 38 saltcake samples analyzed by Swingle. ${ }^{6}$ Figure 4 shows the free liquid decanted from the sample, before and after filtering. The free liquid was light yellow and contained brown suspended solids.

On September 11, 2003, SRTC received two supernate samples from Tank $38 \mathrm{H}$. The two Tank $38 \mathrm{H}$ surface dip samples (200-mL capacity HTF-E-03-122 and 80-mL capacity HTF-E-03-123) contained a combined $\sim 230 \mathrm{~mL}$ of supernate. Figure 5 contains a picture of the Tank $38 \mathrm{H}$ unfiltered supernate samples after being composited in a glass beaker. The samples contained clear yellow liquid with little visual indication of insoluble solids. 
WSRC-TR-2004-00129

Revision 0

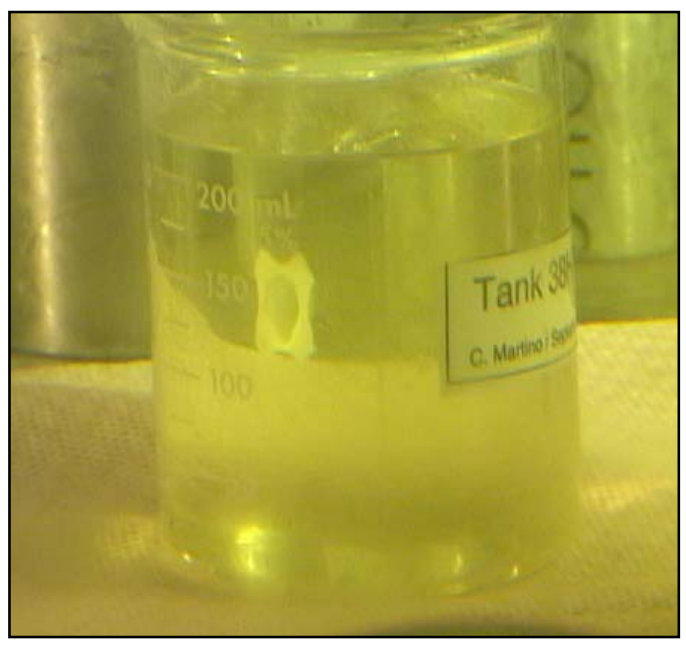

Figure 5: Tank 38H supernate samples HTF-E-03-122 and 123, as received (unfiltered)

\section{Experimental}

\section{Chemical and Radiological Analysis}

\section{Saltcake Core Sample (HTF-E-03-114)}

The Tank 38H sample (HTF-E-03-114) was weighed, uncapped, and visually inspected upon receipt in the shielded cells. The free liquid was decanted and filtered through a 0.45 -micron filter prior to analysis. The remainder of the salt was removed from the tube and mixed. The white chunks were crushed with a pestle to distribute them homogeneously throughout the sample. Portions of this homogenized sample were used for the undrained bulk salt characterization.

Undrained, crushed bulk salt subsamples were prepared for analysis either by aqua regia (acid) dissolution or by deionized (DI) water dissolution. The dissolutions were performed by dissolving approximately 2 grams of the material into $100 \mathrm{~mL}$ of liquid. For the dissolutions into DI water, the salt was added to the water, agitated, settled, then subsampled for analysis. The aqua regia dissolutions were submitted to radiological chemistry for ${ }^{137} \mathrm{Cs}$ (gamma scan), Pu isotopics, and ${ }^{90} \mathrm{Sr}$; inductively coupled plasma - emission spectroscopy (ICP-ES) for elemental analysis; inductively coupled plasma - mass spectroscopy (ICP-MS) for certain actinide and fission product quantification, and atomic absorption (AA) spectroscopy for the measurement of As, Se, Hg, and K. The water dilutions/dissolutions were submitted for ion chromatography (IC) for anion characterization; wet chemistry/titration for total base; free hydroxide, and $\mathrm{CO}_{3}{ }^{2-}$ analysis, and total inorganic and organic carbon (TIC/TOC) analysis. Cations were analyzed by IC analysis to investigate the presence of ammonia and methylamines. An additional portion of the water-dissolved sample was submitted for ${ }^{14} \mathrm{C}$ analysis.

The decanted and filtered free liquid samples were prepared for analysis by dilution with either $2 \mathrm{M}$ $\mathrm{HNO}_{3}$ or DI water. The dilutions were performed by adding the dilution fluid to approximately 2 grams of the filtered free liquid until the final volume was $100 \mathrm{~mL}$. The acid and water dilutions were analyzed by the same methods as the undrained bulk salt dissolutions, with the omission of $A A$ spectroscopy.

Several analytes require assumptions to be made or calculations and adjustments that require several analytical methods. The ${ }^{99} \mathrm{Tc}$ is reported as a maximum value based on the entire mass 99 data, and thus ignores any contribution of ${ }^{99} \mathrm{Ru}$. The mass 101 values are reported in the appendix in case adjustment of ${ }^{99} \mathrm{Tc}$ for the contribution of natural Ru is desired. Total $\mathrm{Cs}$ is calculated as the 
sum of ${ }^{133} \mathrm{Cs}$ from ICP-MS and ${ }^{137} \mathrm{Cs}$ from radiochemistry. The ${ }^{135} \mathrm{Cs}$ is reported as a maximum value based on the entire mass 135 data, and thus ignores any contribution of ${ }^{135} \mathrm{Ba}$. This provides a good measurement for the filtered liquid samples because of the limited Ba solubility, but mass 138 values are reported in the appendix in case adjustment of ${ }^{135} \mathrm{Cs}$ for the contribution of natural $\mathrm{Ba}$ is desired. Total $\mathrm{Co}$ is reported as mass 59 , and thus may be biased high in the presence of organic components that fragment at mass 59. An alternative free hydroxide estimate is provided as a calculated value by taking the total base and subtracting the contribution of aluminate and carbonate ions. Total inorganic carbon is reported as mass of $\mathrm{CO}_{3}{ }^{2-}$ and total organic carbon is reported as mass of carbon.

The total strontium in the saltcake sample was estimated based on the ICP-MS measurement of mass 88 , assuming a natural abundance of ${ }^{86} \mathrm{Sr}$ and ${ }^{87} \mathrm{Sr}$, and combining it with the mass of ${ }^{90} \mathrm{Sr}$ from radiochemistry counting. This causes a small overestimation of the total strontium as the ${ }^{86} \mathrm{Sr}$ and ${ }^{87} \mathrm{Sr}$ would actually be less abundant because some of the ${ }^{88} \mathrm{Sr}$ is present as a fission product. We can estimate that this is around $10 \%$ or less of the total strontium however, because the uranium fission yield of ${ }^{90} \mathrm{Sr}$ is higher than for ${ }^{88} \mathrm{Sr}$, and the ${ }^{90} \mathrm{Sr}$ is $9 \%$ of the mass 88 value. This does not account for decay of the ${ }^{90} \mathrm{Sr}$ during tank storage, as such a correction would require knowledge of the waste history.

Supernatant Liquid Samples (HTF-E-03-122 and 123)

Upon entry into the SRTC shielded cells, the samples (HTF-E-03-122 and 123) were compositied in a glass beaker and visually observed (see Figure 5). Small $(2 \mathrm{~mL})$ portions of the as-received samples were retained for unfiltered analysis. The samples were filtered through 0.45 -micron filters and portions of the filtered samples were analyzed. The solids on the filters were washed with water and dried for determination of sample solids content.

Unfiltered and filtered supernate samples were prepared for analysis either by pressurized $\mathrm{HNO}_{3} / \mathrm{HF}$ (acid) dissolution or by DI water dilution. The dissolutions/dilutions were performed by dissolving/diluting approximately 2 grams of the sample with $100 \mathrm{~mL}$ of liquid. Pressurized $\mathrm{HNO}_{3} / \mathrm{HF}$ dissolutions of the filtered and unfiltered samples were submitted to radiological chemistry for ${ }^{137} \mathrm{Cs}$ (gamma scan), Pu isotopics, ${ }^{241} \mathrm{Am}$, and ${ }^{90} \mathrm{Sr}$; inductively coupled plasma - emission spectroscopy (ICP-ES) for elemental analysis; inductively coupled plasma - mass spectroscopy (ICP-MS) for certain actinide and fission product quantification; and atomic absorption (AA) spectroscopy for the measurement of As, Se, $\mathrm{Hg}$, and $\mathrm{K}$. The water dilutions of the filtered samples were submitted for ion chromatography (IC) for anion characterization; wet chemistry/titration for total base and free hydroxide; and total inorganic and organic carbon (TIC/TOC) analysis. Total inorganic carbon is reported as mass of $\mathrm{CO}_{3}^{2-}$ and total organic carbon is reported as mass of carbon. An additional portion of the water-diluted sample was submitted for ${ }^{14} \mathrm{C}$ analysis.

\section{Physical Properties Analysis}

\section{Density, Moisture, and Percent Interstitial Liquid}

One gram samples of saltcake and salt solutions (supernate liquid and free liquid) were dried to a constant weight in an oven at $115^{\circ} \mathrm{C}\left( \pm 5^{\circ} \mathrm{C}\right)$ to measure gravimetric water content $\left(\theta_{\text {water }}\right)$. Bulk density of the undrained saltcake was determined from direct measurements of sample volume and weight while the sample was still in the thin walled sample tube. Densities of the salt solutions were measured in $2 \mathrm{~mL}$ Class A volumetric flasks.

\section{Viscosity}

Viscosity measurements were performed on the Tank $38 \mathrm{H}$ samples using a Brookfield Model LVDV-E viscometer and Brookfield UL adapter. The geometry of the UL adapter is cylindrical. The 
viscometer/adapter is a Searle type measuring system, where both the rotational speed and torque are measured on the same rotating axis. The UL adapter is designed to couple with the LVDV-E to measure the viscosity of fluids ranging from 1 to 2000 centipoise (cP). The UL adaptor has a water jacket, where the temperature of the sample can be controlled. The water jacket was connected to a heating/cooling recirculation bath. The viscometer/adaptor was initially functionally checked using a National Institute of Standards and Technology (NIST) traceable Newtonian standard prior to radioactive operations. A salt solution $(\sim 8 \mathrm{M} \mathrm{NaOH})$ was made and the viscosity measured using a Haake RS600 rheometer at $6.4 \mathrm{cP}\left(@ 25^{\circ} \mathrm{C}\right)$. A salt solution was selected as a means to verify the functionality of the Brookfield viscometer/adapter in the cells, due to the fact the NIST traceable Newtonian standards are usually made of silicon oil and cleaning this oil from the UL adapter in the cells could not be achieved to the level required. The viscometer/adapter measured the average viscosity of the $8 \mathrm{M} \mathrm{NaOH}$ solution at $6.55 \mathrm{cP}$ (ranged from 6.51 to $6.63 \mathrm{cP}$ ) $25^{\circ} \mathrm{C}$ prior to radioactive operations. The UL adaptor was cleaned by rinsing with DI water to remove the salt solution from the wetted surfaces. The $8 \mathrm{M} \mathrm{NaOH}$ solution was subdivided into $25 \mathrm{~mL}$ bottles to be used in the shielded cells. During pre-radioactive operation bench tests, it took approximately 3 minutes for isothermal conditions to exist in the $\mathrm{UL}$ adapter at set temperatures ranging from $25^{\circ} \mathrm{C}$ to $50{ }^{\circ} \mathrm{C}$.

\section{Microscopy and Spectroscopy}

Portions of the solids contained within the free liquid decanted from the saltcake core sample were washed, dried, and investigated by microscopic and spectroscopic methods. The material was investigated by scanning electron microscopy (SEM) with energy dispersive spectroscopy (EDS) and by X-ray diffraction (XRD). Preparation for SEM involved drying and plating the material with Au and $\mathrm{Pd}$.

\section{Results and Discussion}

Tabulated results for the undrained saltcake are reported in the report body and in the appendix as the average and the standard deviation of the analysis of triplicate dissolutions. The free liquid and supernatant liquid results are reported as the average of two or three analyses of a single dilution or dissolution, with the standard deviation only appearing in the appendix. Values reported as their detection limits are preceded by " $<$ " and values that contain an average of detectable concentrations and detection limits are preceded by " $<=$ =". Blank values in the tables, "--", are either not determined or not applicable.

\section{Physical Analysis}

Table 1 contains a compilation of the physical properties of the Tank $38 \mathrm{H}$ saltcake and salt solution samples. The average and standard deviations for several determinations of water content and density measurements are provided. The undrained saltcake is the bulk core sample material after removal of the free liquid. The free liquid (FL) is the liquid that was decanted from the salt in the tube that the core sample was received in. The supernatant liquid (SL) is the liquid surface samples that were collected separately. The SL was analyzed both filtered and unfiltered.

Due to the nature of the saltcake core sample, the bulk density could not be determined using the same protocol as previous saltcake samples. It is expected that the saltcake bulk density is approximately that of the other wet saltcakes studied, or about $2 \mathrm{~g} / \mathrm{cm}^{3}$. Upon review of the entire set of data, it was determined that a bulk undrained saltcake density of $2 \mathrm{~g} / \mathrm{cm}^{3}$ would lead to a pore saturation of greater than $100 \%$, which is physically impossible. This largely sodium nitrate solid phase with some sulfates and carbonates would have a solid crystal density of approximately 2.3 $\mathrm{g} / \mathrm{cm}^{3}$. From this value, and using the water content of the saltcake and interstitial liquid and assuming $100 \%$ saturation of the pores, the undrained saltcake bulk density was estimated as 1.94 $\mathrm{g} / \mathrm{cm}^{3}$. 
The Tank $38 \mathrm{H}$ saltcake contained in HTF-E-03-114 had a water content of $16.8 \mathrm{wt} \%$ with a standard deviation of $0.6 \mathrm{wt} \%$. The Free Liquid (FL) in HTF-E-03-114 had a density of $1.430 \mathrm{~g} / \mathrm{cm}^{3}$ with a standard deviation of $0.001 \mathrm{~g} / \mathrm{cm}^{3}$, determined from two measurements. The Tank $38 \mathrm{H}$ Supernate Liquid (SL) (HTF-E-03-122 and 123) had a density of $1.45 \mathrm{~g} / \mathrm{cm}^{3}$ with a standard deviation from four measurements of $0.03 \mathrm{~g} / \mathrm{cm}^{3}$. The supernate samples had a total solids content (which is approximately all soluble solids) of $45.6 \mathrm{wt} \%$ with a standard deviation from three measurements of 0.4 wt \%.

The interstitial liquid (IL) content of the Tank $38 \mathrm{H}$ saltcake is calculated with the following two equations.

$$
\text { (IL) Interstitial Liquid in Saltcake (wt \%) }=\frac{\text { Water in Saltcake (wt \%) }}{\text { Water in Liquid (wt \%) }}
$$

$$
\text { (IL) Interstitial Liquid in Saltcake }\left(\text { vol \%) }=\text { Liquid in Saltcake }(w t \%) \times \frac{\text { Density of Saltcake }(\mathrm{g} / \mathrm{mL})}{\text { Density of Liquid }(\mathrm{g} / \mathrm{mL})}\right.
$$

Because interstitial liquid was never drained from the Tank $38 \mathrm{H}$ sample for measurement, the interstitial liquid properties are not known. It is likely that the free liquid in the core sample was similar in composition to the interstitial liquid. The free liquid, however, was not dried to determine water content. Thus, the interstitial liquid properties used in evaluating the percent interstitial liquid in saltcake are the density of the free liquid and the water content of the supernatant liquid. The volume percent interstitial liquid in the original saltcake, and thus the porosity at $100 \%$ saturation, was estimated as $42 \mathrm{vol} \%$.

Table 1: Summary of physical aspects of the Tank $38 \mathrm{H}$ samples

\begin{tabular}{|c|c|c|c|c|c|c|c|c|c|}
\hline \multirow{2}{*}{ Analyte } & \multirow{2}{*}{ Unit } & \multicolumn{4}{|c|}{ HTF-E-03-114 } & \multicolumn{4}{c|}{ HTF-E-03-122, 123 } \\
\cline { 3 - 11 } & & & undrained saltcake & \multicolumn{2}{|c|}{ FL (filtered) } & \multicolumn{2}{|c|}{ SL (unfiltered) } & \multicolumn{2}{c|}{ SL (filtered) } \\
\cline { 3 - 10 } & & average & stdev & average & stdev & average & stdev & average & stdev \\
\hline Density & g/mL & 1.94 & -- & 1.43 & 0.001 & 1.45 & 0.03 & 1.45 & 0.03 \\
\hline Water & wt \% & 16.8 & 0.6 & $\sim 58$ & -- & 54.4 & 0.4 & 54.4 & 0.4 \\
\hline Liquid & wt \% & 30.9 & -- & 100 & -- & $>99.9$ & -- & 100 & -- \\
\hline Liquid & vol \% & 42 & -- & 100 & -- & $>99.9$ & -- & 100 & -- \\
\hline Porosity & vol \% & 42 & -- & N/A & -- & N/A & -- & N/A & -- \\
\hline Saturation & vol \% & 100 & -- & N/A & -- & N/A & -- & N/A & -- \\
\hline
\end{tabular}

FL water content was estimated from a mass balance summing individual anions and cations Density and Porosity of undrained saltcake are estimated values Water in wt $\%$ is $\theta_{w}$ for saltcake

The viscosity of the filtered composited Tank $38 \mathrm{H}$ supernate samples (HTF-E-03-122 and 123) was measured at thee temperatures: $25^{\circ} \mathrm{C}, 35^{\circ} \mathrm{C}$, and $50^{\circ} \mathrm{C}$. Steady state measurements were recorded and the results are shown in Figure 6 . The viscometer/adaptor was installed into the shielded cells and functionally checked using the $8 \mathrm{M} \mathrm{NaOH}$ solution at $6.59 \mathrm{cP}$ at $25^{\circ} \mathrm{C}$ prior to starting the viscosity measurements of the waste sample. The data was fitted to an exponential equation and the equation is shown in Figure 6 . The fitted equation can only be used in the temperature range $\left(25^{\circ} \mathrm{C}\right.$ to $\left.50^{\circ} \mathrm{C}\right)$ in which it was fitted. 


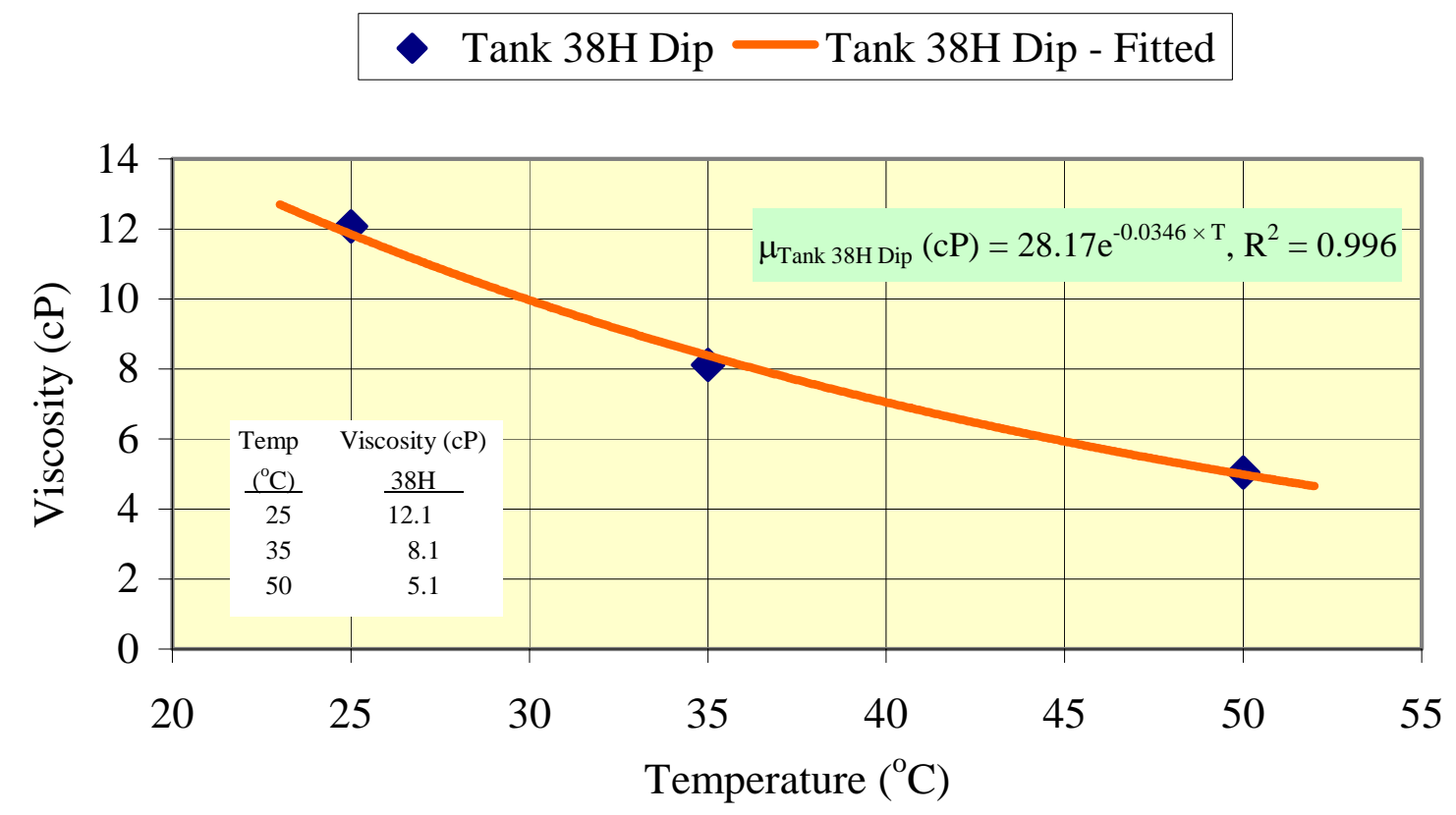

Figure 6: Viscosity of the Tank 38H Supernate Samples HTF-E-03-122 and 123 Composite.

\section{Chemical and Radiological Analysis}

\section{Undrained Saltcake}

Tables 2 through 5 (and Table 7 through Table 11 in the Appendix) contain the characterization information for the Tank 38H undrained bulk saltcake sample (HTF-E-03-114), reported as the average and the standard deviation of the analysis of triplicate dissolutions. The ${ }^{137} \mathrm{Cs}$ activity of the sample was $3.72 \mathrm{E}+7 \mathrm{pCi} / \mathrm{g}$, which corresponds to approximately $0.3 \mathrm{Ci}$ per gallon of saltcake. The ${ }^{238} \mathrm{Pu}$ activity of the bulk saltcake was $3.62 \mathrm{E}+6 \mathrm{pCi} / \mathrm{g}$.

The analysis of cations (ammonium and methylamines) was performed on water-dissolved Tank $38 \mathrm{H}$ saltcake to determine the cause of an ammonia odor noticed upon sample transfer into the shielded cells. No ammonium of methylamines were detected by ion chromatography. Unfortunately, however, the minimum detectable limit of ammonium and methylamines was very high due to sample dilution and analytical interferences with sodium, the primary cation. The detection limit for ammonium, methylamine, and dimethylamine was $870 \mathrm{mg} / \mathrm{L}$. The detection limit for trimethylamine was $4400 \mathrm{mg} / \mathrm{L}$. Also, under caustic conditions, ammonium in the sample would be converted to ammonia and potentially driven into the vapor phase during sample storage and preparation, so their absence in the original sample cannot be confirmed by this analysis.

Based on the assumptions listed previously, the total strontium in the Tank $38 \mathrm{H}$ sample was estimated at $4.26 \mathrm{E}-5 \mathrm{wt} \%$. Apparently, a large fraction $(\sim 80 \%)$ of the strontium in this waste sample is from exterior sources, possibly from chemical reagent impurities. ${ }^{90} \mathrm{Sr}$ is $9 \%$ of the total strontium.

\section{Free and Supernatant Liquid}

Tables 2 through 5 (and Table 12 through Table 15 in the appendix) contain the analysis of the free liquid associated with the Tank $38 \mathrm{H}$ saltcake. Results are reported as the average of duplicate analyses of the filtered and diluted free liquid sample. The ${ }^{137} \mathrm{Cs}$ activity of the free liquid was 
$1.93 \mathrm{E}+8 \mathrm{pCi} / \mathrm{mL}$, which corresponds to $0.73 \mathrm{Ci} / \mathrm{gal}$. The ${ }^{238} \mathrm{Pu}$ activity of the filtered free liquid was $5.78 \mathrm{E}+3 \mathrm{pCi} / \mathrm{mL}$, which is significantly lower than the ${ }^{238} \mathrm{Pu}$ activity of the bulk saltcake.

Tables 2 through 5 (and Tables 17 through 21 in the appendix) contain the data from the analysis of the Tank $38 \mathrm{H}$ supernate liquid composite (samples HTF-E-03-122 and 123). The average and standard deviation of duplicate analyses of a single diluted sample are provided. The ${ }^{137} \mathrm{Cs}$ activity of the as-received and the filtered samples were $1.7 \mathrm{E}+8 \mathrm{pCi} / \mathrm{mL}$, which corresponds to $0.65 \mathrm{Ci} / \mathrm{gal}$. The ${ }^{238} \mathrm{Pu}$ and ${ }^{239 / 240} \mathrm{Pu}$ in the as-received sample sum to $2.33 \mathrm{E}+4 \mathrm{pCi} / \mathrm{mL}$, and filtration was not effective in removal of $\mathrm{Pu}$.

\section{Comparison of Components and Streams}

Table 2, Table 3, and Table 4 contain summaries of the radiological, ionic, and elemental composition, respectively, of the undrained saltcake, the filtered free liquid (FL), and the unfiltered and filtered supernatant liquid (SL). The characterization results for both the solid and the liquid streams are presented in per mass units.

The right-most column of Table 2 through Table 4, labeled "Partition into IL (\%)", is an estimate for each component of the percentage measured in the undrained saltcake that was contained in the interstitial liquid residing in the saltcake pores. Subtracting the "Partition into IL" from $100 \%$ yields an estimate for each component of the percentage contained in the solid phase of the original saltcake sample. To calculate the value reported as the "Partition into IL" for each component, the wt $\%$ of the component measured in the filtered free liquid is multiplied by the wt \% of IL in the undrained saltcake and divided by the wt \% of the component measured in the undrained saltcake. In cases where the FL was not measured for a component, the value was calculated using the composition of the filtered supernate instead of the free liquid. The relative error in all of these calculated values is roughly $25 \%$.

The "Partition into IL" for many components is statistically indistinguishable from $100 \%$, including cesium, nitrite, hydroxide, phosphate, formate, and potassium. Some components, conversely, are present in the interstitial liquid at much lower levels than in the saltcake solids, including uranium, plutonium, strontium, sulfate, fluoride, oxalate, and iron. Several other components appear to be contained in both the interstitial liquid and the saltcake solids, including sodium, nitrate, carbonate, and chromium. Although technetium also appears to be distributed into both phases, the large standard deviation in the bulk saltcake analysis prohibits conclusive proof that some insoluble technetium exists, although it is not unreasonable that some could be associated with sludge solids.

Table 3 contains several values that are determined from multiple analytical techniques. The mass balance for each stream is calculated by summing the analytes in Table 3 that are above detection limits and the water content in Table 1. The charge balance for each stream is calculated by summing the normalities of the anions and dividing by the sum of the normalities of the cations. The calculated hydroxide concentration is used to check the measured free hydroxide titration. It estimates the free hydroxide by taking the total base measured by titration and subtracting the carbonate by TIC and the aluminate by ICP-ES. Total cesium is calculated as the sum of ${ }^{133} \mathrm{Cs}$ by ICP-MS and the ${ }^{137} \mathrm{Cs}$ from rad. chem. Several other components (phosphate, sulfate, and potassium) have also been measured by two equally valid methods.

The ${ }^{137} \mathrm{Cs}$ activity in the free liquid associated with the saltcake core sample $(0.73 \mathrm{Ci} / \mathrm{gal})$ was only slightly higher than that in the surface supernate sample $(0.65 \mathrm{Ci} / g a l$.$) .$

Table 5 shows calculated projections of the liquid streams produced during tank draining and dissolution. The free liquid and the supernatant liquid (converted to molarity from the values in the previous summary tables) is assumed to be representative of the material in the full-scale tank that would be removed during draining. The sample, however, corresponded to only a small vertical portion of the saltcake, so the composition of the liquid at different tank elevations may differ. The other streams contained in Table 5 are the undrained dissolved salt (UDS-0) and the projected 
composition of drained dissolved salt following removal of $25 \%, 50 \%$, and $100 \%$ of the interstitial liquid (DDS-25, DDS-50, and DDS-100, respectively). The undrained dissolved salt and the drained dissolved salt streams are compared at a total sodium ion concentration of $6 \mathrm{M}$. These $6 \mathrm{M}\left[\mathrm{Na}^{+}\right]$ stream calculations do not account for the solubility of the individual components in the saltcake. The values for these dissolved salt streams contain the contribution from the solids present, which would include some less soluble salts and water insoluble solids. The dissolved salt streams are average values for the complete dissolution (or slurrying) of the saltcake and do not account for selective or partial dissolution. During dissolution processes occurring over several stages with liquid movement within the saltcake, the more soluble components, such as $\mathrm{OH}^{-}, \mathrm{NO}_{2}^{-}$, and ${ }^{137} \mathrm{Cs}$, would be more concentrated in earlier stages while less soluble components, such as $\mathrm{CO}_{3}{ }^{2-}$ and $\mathrm{SO}_{4}{ }^{2-}$, would be more concentrated in the later stages. ${ }^{8}$

Also included in Table 5 are values for each stream indicating the grams of salt required to produce a $6 \mathrm{M}\left[\mathrm{Na}^{+}\right]$solution. An estimate of the amount of sludge that could be contained in the dissolved salt solutions is calculated from the concentration of iron, chromium, and manganese in the saltcake. The estimate does not contain contributions by silicon, aluminum, and radionuclides. The composition of the sludge used in the estimate is approximately $90 \mathrm{wt} \% \mathrm{Fe}(\mathrm{OH})_{3}, 5 \mathrm{wt} \% \mathrm{MnO}_{2}$, and $5 \mathrm{wt} \% \mathrm{Cr}(\mathrm{OH})_{3}$ as anhydrous solids.

This study did not include an analysis of the residual insoluble solids that resulted from salt dissolution. It is likely that the residual material would contain some sludge solids (iron and manganese oxides or hydroxides with uranium and plutonium) and some aluminum and silicon. Because such solids were not collected and analyzed, however, we are unable to formulate a "Partition into Residual Solids", comparable to what was formulated for the interstitial liquid. Future characterization of saltcake core samples will be performed in such a manner as to allow for quantifying the contribution of the residual insoluble materials. Such information would help to determine, for example, how much plutonium may be removed by filtration or settling.

Figure 7 and appendix Table 16 indicate the likely composition of the solid phase in the original undrained sample. This composition is formulated from the major components of saltcake in which all interstitial liquid has been removed. The removal of interstitial liquid is done by calculation in a similar manner to the formulation of DDS-100. Information on the original percentage interstitial liquid in the undrained saltcake is used to adjust the bulk saltcake composition by subtracting out the contribution of the interstitial liquid. Finally, the saltcake composition is normalized to sum to $100 \mathrm{wt} \%$. The unnormalized composition summed to only $90 \mathrm{wt} \%$, which is a reasonably good material balance considering the number of individual analytical measurements.

Table 6 contains a comparison of some of the radiological and elemental results for the undrained bulk saltcake (HTF-E-03-114) with previous nuclear criticality safety samples. Each of these previous samples was a three-inch-long saltcake sample (or set of samples) from the Tank $38 \mathrm{H}$ supernate/saltcake interface. The first sample, pulled in 1996, was near the period when the $2 \mathrm{H}-$ evaporator system began to be utilized primarily as the means to concentrate the DWPF recycle material. The next two samples for which bulk saltcake characterization was performed were collected in July 2000 and July 2001. Analytes for which the previous or current analyses provided no data are indicated by "--".

The ${ }^{137} \mathrm{Cs}$ activity in the current saltcake bulk sample matches the levels observed previously in the July 2000 and July 2001 samples. Alpha activity from actinides in the current sample, however, is significantly lower than that for the July 2000 and July 2001 samples. In general, uranium, plutonium and neptunium contents were lowest in the 1996 sample, highest in the July 2000 and July 2001 samples, and decreased significantly in the September 2003 samples. In the July 2000 sample, ${ }^{90} \mathrm{Sr}$ contributes significantly to the gross beta measurement. The July 2000 and July 2001 samples have greater-than-three-times the plutonium activity than the current sample. The July 2000 sample also had a measurable activity of ${ }^{241} \mathrm{Am}(2.05 \mathrm{E}+5 \mathrm{pCi} / \mathrm{g})$. The isotopic distribution of plutonium is similar for all samples. The isotopic distribution of uranium, however, is different for the recent sample with the ${ }^{235} \mathrm{U}$ enrichment lowered to $0.72 \%$. This is likely due to the addition of 21,000 gal. of depleted uranyl carbonate to Tank 43H in August 2001 as part of the enrichment control program. ${ }^{9}$ 
The trends in the sample results may actually represent changes in the surface of the Tank $38 \mathrm{H}$ saltcake, assuming that they are not solely due to tank heterogeneity. The 1996 sample had the smaller amounts of the largely insoluble actinides. During the time period when the July 2000 and July 2001 samples were taken, the HLW process chemistry group noted that the Tank $38 \mathrm{H}$ saltcake surface dropped from 261 inches to 242.5 inches. ${ }^{10}$ It is likely that the addition of unsaturated evaporator concentrates from the evaporation of DWPF recycle dissolved approximately 20 inches of the Tank $38 \mathrm{H}$ saltcake. This possibly resulted in a layer of the more insoluble components to form at the top of the Tank $38 \mathrm{H}$ saltcake. This layering effect may impact retrieval and salt dissolution rates, depending on the water addition method. The $2 \mathrm{H}$ evaporator system was largely inactive at the time the layer at the Tank 38H saltcakes surface was sampled in July 2000 and July 2001 . Because Tank $38 \mathrm{H}$ was more active as the $2 \mathrm{H}$-evaporator system was reactivated in late 2001 , some saltcake may have been deposited or mixed with this layer before the September 2003 Tank $38 \mathrm{H}$ sample was taken.

The actinides (plutonium, uranium, and neptunium) and strontium in the current Tank $38 \mathrm{H}$ saltcake core sample are high compared with recent Tank $41 \mathrm{H}$ samples. ${ }^{11}$ This is likely due to the sampling of the sludgy layer in Tank $38 \mathrm{H}$ that was more concentrated in these sparingly soluble species.

Table 2: Summary of radioactive components in Tank $38 \mathrm{H}$ samples

\begin{tabular}{|c|c|c|c|c|c|c|c|c|}
\hline \multirow{3}{*}{ Analyte } & \multirow{3}{*}{ Units } & \multirow{3}{*}{ Method } & \multicolumn{3}{|c|}{ HTF-E-03-114 } & \multicolumn{2}{|c|}{ HTF-E-03-122, 123} & \multirow{3}{*}{$\begin{array}{c}\text { Partition Into } \\
\text { IL (\%) }\end{array}$} \\
\hline & & & \multicolumn{2}{|c|}{ undrained saltcake } & \multirow{2}{*}{ FL (filtered) } & \multirow{2}{*}{ SL (unfiltered) } & \multirow{2}{*}{ SL (filtered) } & \\
\hline & & & Average & StDev & & & & \\
\hline${ }^{14} \mathrm{C}$ & $\mathrm{pCi} / \mathrm{g}$ & Rad. Chem. & $5.6 \mathrm{E}+03$ & -- & -- & -- & $<8.41 E+02$ & $<5$ \\
\hline${ }^{90} \mathrm{Sr}$ & $\mathrm{pCi} / \mathrm{g}$ & Rad. Chem. & $5.24 \mathrm{E}+06$ & $1.84 \mathrm{E}+06$ & $4.3 E+04$ & $2.03 E+04$ & $1.01 \mathrm{E}+04$ & 0.3 \\
\hline${ }^{99} \mathrm{Tc}$ & $\mathrm{pCi} / \mathrm{g}$ & ICP-MS & $1.5 \mathrm{E}+04$ & $4 \mathrm{E}+03$ & $3.47 E+04$ & $3.44 \mathrm{E}+04$ & $3.43 E+04$ & 71 \\
\hline${ }^{135} \mathrm{Cs}$ & $\mathrm{pCi} / \mathrm{g}$ & ICP-MS & $1.8 \mathrm{E}+02$ & $2 \mathrm{E}+01$ & $4.9 \mathrm{E}+02$ & $5.2 \mathrm{E}+02$ & $5.0 \mathrm{E}+02$ & 85 \\
\hline${ }^{137} \mathrm{Cs}$ & $\mathrm{pCi} / \mathrm{g}$ & Rad. Chem. & $3.72 \mathrm{E}+07$ & $2.5 \mathrm{E}+06$ & $1.35 E+08$ & $1.19 \mathrm{E}+08$ & $1.17 \mathrm{E}+08$ & 112 \\
\hline${ }^{230} \mathrm{Th}$ & $\mathrm{pCi} / \mathrm{g}$ & ICP-MS & $<1.7 E+03$ & -- & $<2.3 E+03$ & $<1.1 E+03$ & $<1.0 E+03$ & -- \\
\hline${ }^{232} \mathrm{Th}$ & $\mathrm{pCi} / \mathrm{g}$ & ICP-MS & $2.5 \mathrm{E}-01$ & $2 \mathrm{E}-02$ & $<1.2 E-02$ & $<5.5 E-03$ & $<5.4 E-03$ & $<1$ \\
\hline${ }^{233} \mathrm{U}$ & $\mathrm{pCi} / \mathrm{g}$ & ICP-MS & $<7.7 E+02$ & -- & $<1.0 E+03$ & $<4.9 E+02$ & $<4.7 E+02$ & -- \\
\hline${ }^{234} U$ & $\mathrm{pCi} / \mathrm{g}$ & ICP-MS & $6.6 \mathrm{E}+03$ & $5 E+02$ & $<6.7 E+02$ & $<3.1 E+02$ & $<3.1 E+02$ & $<1$ \\
\hline${ }^{235} \mathrm{U}$ & $\mathrm{pCi} / \mathrm{g}$ & ICP-MS & $7.2 \mathrm{E}+00$ & $1.1 \mathrm{E}+00$ & $2.6 \mathrm{E}-01$ & $3.16 \mathrm{E}-01$ & $2.65 \mathrm{E}-01$ & 1 \\
\hline${ }^{236} U$ & $\mathrm{pCi} / \mathrm{g}$ & ICP-MS & $3.4 \mathrm{E}+01$ & $3 E+00$ & $<6.9 E+00$ & $<3.2 E+00$ & $<3.2 E+00$ & $<3$ \\
\hline${ }^{237} \mathrm{~Np}$ & $\mathrm{pCi} / \mathrm{g}$ & ICP-MS & $3.6 \mathrm{E}+02$ & $2 \mathrm{E}+01$ & $<7.6 E+01$ & $<3.5 E+01$ & $<3.4 E+01$ & $<3$ \\
\hline${ }^{238} \mathrm{U}$ & $\mathrm{pCi} / \mathrm{g}$ & ICP-MS & $1.55 \mathrm{E}+02$ & $2.3 \mathrm{E}+01$ & $2.95 \mathrm{E}+00$ & $9.38 \mathrm{E}+00$ & $9.30 \mathrm{E}+00$ & 1 \\
\hline${ }^{238} \mathrm{Pu}$ & $\mathrm{pCi} / \mathrm{g}$ & Rad. Chem. & $3.62 \mathrm{E}+06$ & $3.3 \mathrm{E}+05$ & $4.04 \mathrm{E}+03$ & $1.51 \mathrm{E}+04$ & $1.59 \mathrm{E}+04$ & 0.03 \\
\hline${ }^{239 / 240} \mathrm{Pu}$ & $\mathrm{pCi} / \mathrm{g}$ & Rad. Chem. & $6.46 \mathrm{E}+04$ & $2.84 \mathrm{E}+04$ & $7.1 \mathrm{E}+02$ & $9.53 \mathrm{E}+02$ & $1.06 \mathrm{E}+03$ & 0.3 \\
\hline${ }^{239} \mathrm{Pu}$ & $\mathrm{pCi} / \mathrm{g}$ & ICP-MS & $3.4 \mathrm{E}+04$ & $1.0 \mathrm{E}+04$ & $<6.7 E+03$ & $<3.1 E+03$ & $<3.0 E+03$ & $<3$ \\
\hline${ }^{240} \mathrm{Pu}$ & $\mathrm{pCi} / \mathrm{g}$ & ICP-MS & $3.4 \mathrm{E}+04$ & $1.3 \mathrm{E}+04$ & $<2.4 E+04$ & $<1.1 E+04$ & $<1.1 E+04$ & $<10$ \\
\hline${ }^{241} \mathrm{Pu}$ & $\mathrm{pCi} / \mathrm{g}$ & ICP-MS & $<8.2 E+06$ & -- & $<1.1 E+07$ & $<5.2 E+06$ & $<5.0 E+06$ & -- \\
\hline${ }^{241} \mathrm{Am}$ & $\mathrm{pCi} / \mathrm{g}$ & ICP-MS & $<2.7 E+05$ & -- & $<3.7 E+05$ & $<1.7 E+05$ & $<1.7 E+05$ & -- \\
\hline${ }^{242} \mathrm{Pu}$ & $\mathrm{pCi} / \mathrm{g}$ & ICP-MS & $7.3 \mathrm{E}+02$ & $5 E+01$ & $<4.1 E+02$ & $<1.9 E+02$ & $<1.9 E+02$ & $<8$ \\
\hline \multicolumn{9}{|c|}{ Uranium Summary } \\
\hline Total U & wt $\%$ & ICP-MS & 4.66E-02 & $6.9 \mathrm{E}-03$ & 8.0E-04 & 2.81E-03 & 2.78E-03 & 1 \\
\hline${ }^{235} \mathrm{U}$ Enrichment & wt $\%$ & ICP-MS & $0.72 \%$ & $0.01 \%$ & $1 \%$ & $0.52 \%$ & $0.44 \%$ & -- \\
\hline
\end{tabular}


WSRC-TR-2004-00129

Revision 0

Table 3: Summary of ionic components in Tank $38 \mathrm{H}$ samples

\begin{tabular}{|c|c|c|c|c|c|c|c|c|}
\hline \multirow{3}{*}{ Analyte } & \multirow{3}{*}{ Units } & \multirow{3}{*}{ Method } & \multicolumn{3}{|c|}{ HTF-E-03-114 } & \multicolumn{2}{|c|}{ HTF-E-03-122, 123} & \multirow{3}{*}{$\begin{array}{c}\text { Partition Into } \\
\text { IL (\%) }\end{array}$} \\
\hline & & & \multicolumn{2}{|c|}{ undrained saltcake } & \multirow{2}{*}{ FL (filtered) } & \multirow{2}{*}{ SL (unfiltered) } & \multirow{2}{*}{ SL (filtered) } & \\
\hline & & & Average & StDev & & & & \\
\hline $\mathrm{Na}^{+}$ & wt \% & ICP-ES & $2.26 \mathrm{E}+01$ & $1.0 \mathrm{E}+00$ & $1.73 E+01$ & $1.66 \mathrm{E}+01$ & $1.67 \mathrm{E}+01$ & 24 \\
\hline $\mathrm{NO}_{3}$ & wt \% & IC & $4.12 \mathrm{E}+01$ & $5.2 \mathrm{E}+00$ & $9.04 \mathrm{E}+00$ & -- & $9.43 \mathrm{E}+00$ & 7 \\
\hline $\mathrm{NO}_{2}$ & wt $\%$ & IC & $1.80 \mathrm{E}+00$ & 6E-02 & $5.68 \mathrm{E}+00$ & -- & $5.71 \mathrm{E}+00$ & 98 \\
\hline $\mathrm{OH}^{-}$ & wt \% & Wet Chem. & $1.96 \mathrm{E}+00$ & 4.4E-01 & $6.59 \mathrm{E}+00$ & -- & $5.90 \mathrm{E}+00$ & 104 \\
\hline $\mathrm{OH}^{-}$ & wt \% & Calculated & $2.97 \mathrm{E}+00$ & 4.7E-01 & $7.38 \mathrm{E}+00$ & -- & $7.66 \mathrm{E}+00$ & 77 \\
\hline $\mathrm{AlO}_{2}$ & wt \% & ICP-ES & $3.02 \mathrm{E}-01$ & 7E-03 & $6.58 \mathrm{E}-01$ & $4.12 \mathrm{E}-01$ & $6.71 \mathrm{E}-01$ & 67 \\
\hline $\mathrm{CO}_{3}{ }^{2-}$ & wt $\%$ & TIC/TOC & $3.42 \mathrm{E}+00$ & $9.7 \mathrm{E}-01$ & $1.20 \mathrm{E}+00$ & -- & $1.03 E+00$ & 11 \\
\hline $\mathrm{SO}_{4}{ }^{2-}$ & wt \% & IC & $1.59 \mathrm{E}+00$ & $1.5 \mathrm{E}-01$ & $1.59 \mathrm{E}-01$ & -- & 1.17E-01 & 3 \\
\hline $\mathrm{SO}_{4}{ }^{2-}$ & wt $\%$ & ICP-ES & $2.01 \mathrm{E}+00$ & $2.3 \mathrm{E}-01$ & 4.73E-01 & $3.16 \mathrm{E}-01$ & 3.43E-01 & 7 \\
\hline $\mathrm{PO}_{4}{ }^{3-}$ & wt $\%$ & IC & $1.80 \mathrm{E}-02$ & 3.1E-03 & 7.94E-02 & -- & 7.77E-02 & 136 \\
\hline $\mathrm{PO}_{4}{ }^{3-}$ & wt $\%$ & ICP-ES & $<6.94 E-02$ & -- & 1.03E-01 & 9.32E-02 & 8.80E-02 & -- \\
\hline $\mathrm{Cl}^{-}$ & wt \% & IC & $<8.68 E-03$ & -- & $</=1.22 \mathrm{E}-02$ & -- & $9.72 \mathrm{E}-03$ & -- \\
\hline $\mathrm{F}^{-}$ & wt \% & IC & $3.50 \mathrm{E}-02$ & $2.8 \mathrm{E}-03$ & $<1.22 \mathrm{E}-02$ & -- & 4.86E-03 & 4 \\
\hline $\mathrm{C}_{2} \mathrm{O}_{4}{ }^{2-}$ & wt $\%$ & IC & 4.56E-01 & $1.4 \mathrm{E}-02$ & $<6.11 \mathrm{E}-02$ & -- & 1.46E-02 & 1.0 \\
\hline $\mathrm{CHO}_{2}^{-}$ & wt \% & IC & $5.50 \mathrm{E}-02$ & $1.58 \mathrm{E}-02$ & $1.50 \mathrm{E}-01$ & -- & $1.46 \mathrm{E}-01$ & 84 \\
\hline $\mathrm{K}^{+}$ & wt \% & AA & $2.1 \mathrm{E}-02$ & $2 \mathrm{E}-03$ & -- & $6.6 \mathrm{E}-02$ & $6.5 \mathrm{E}-02$ & 95 \\
\hline $\mathrm{K}^{+}$ & wt \% & ICP-ES & $<4.44 E-01$ & - & $<6.01 E-01$ & $<4.64 E-01$ & $<4.52 E-01$ & -- \\
\hline $\mathrm{Cs}^{+}$ & wt \% & ICP-MS/RdChm & $1.53 \mathrm{E}-04$ & 9E-06 & $5.05 \mathrm{E}-04$ & $3.89 \mathrm{E}-04$ & 3.96E-04 & 102 \\
\hline TOC & wt \% & TIC/TOC & $1.3 \mathrm{E}+00$ & $3 \mathrm{E}-01$ & 3.36E-01 & -- & $3.28 \mathrm{E}-01$ & 8 \\
\hline Mass Balance & $\%$ & Calculated & 93 & & $43+$ water & -- & 97 & -- \\
\hline Charge Bal $(-/+)$ & $\%$ & Calculated & 100 & & 96 & -- & 93 & -- \\
\hline
\end{tabular}


Table 4: Summary of other elemental components in Tank $38 \mathrm{H}$ samples.

\begin{tabular}{|c|c|c|c|c|c|c|c|c|}
\hline \multirow{3}{*}{ Analyte } & \multirow{3}{*}{ Units } & \multirow{3}{*}{ Method } & \multicolumn{3}{|c|}{ HTF-E-03-114 } & \multicolumn{2}{|c|}{ HTF-E-03-122, 123} & \multirow{3}{*}{$\begin{array}{c}\text { Partition Into } \\
\text { IL (\%) }\end{array}$} \\
\hline & & & \multicolumn{2}{|c|}{ undrained saltcake } & \multirow{2}{*}{ FL (filtered) } & \multirow{2}{*}{ SL (unfiltered) } & \multirow{2}{*}{ SL (filtered) } & \\
\hline & & & Average & StDev & & & & \\
\hline $\mathrm{Ag}$ & wt $\%$ & ICP-ES & $<6.99 E-04$ & - & $<9.47 E-04$ & $<7.30 E-04$ & $<7.11 E-04$ & -- \\
\hline As & wt $\%$ & AA & $<2.3 E-04$ & - & - & $<2.4 E-04$ & $<2.4 E-04$ & -- \\
\hline $\mathrm{B}$ & wt $\%$ & ICP-ES & $<7.55 E-02$ & -- & $<1.02 E-01$ & $<7.89 E-02$ & $<7.68 E-02$ & -- \\
\hline $\mathrm{Ba}$ & wt $\%$ & ICP-ES & $<6.99 E-04$ & - & $<9.47 E-04$ & $<7.30 E-04$ & $<7.11 E-04$ & -- \\
\hline $\mathrm{Ca}$ & wt $\%$ & ICP-ES & $<2.11 E-02$ & - & $<2.86 E-02$ & $<2.21 E-02$ & $<2.15 E-02$ & -- \\
\hline $\mathrm{Cd}$ & wt $\%$ & ICP-ES & $<9.33 E-04$ & - & $<1.26 E-03$ & $<9.74 E-04$ & $<9.48 E-04$ & -- \\
\hline $\mathrm{Ce}$ & wt $\%$ & ICP-ES & $<1.16 E-02$ & -- & $<1.57 E-02$ & $<1.21 E-02$ & $<1.18 E-02$ & -- \\
\hline Co & wt $\%$ & ICP-MS & 2.7E-05 & 1.0E-05 & $<5.8 E-06$ & $<4.1 E-05$ & $<4.0 E-05$ & -- \\
\hline $\mathrm{Cr}$ & wt $\%$ & ICP-ES & 4.85E-03 & 7.8E-04 & $9.29 \mathrm{E}-03$ & $8.22 \mathrm{E}-03$ & $1.01 \mathrm{E}-02$ & 59 \\
\hline $\mathrm{Cu}$ & wt $\%$ & ICP-ES & $</=3.3 E-02$ & $5.4 \mathrm{E}-02$ & $<1.96 E-03$ & $<1.51 E-03$ & $<1.47 E-03$ & -- \\
\hline $\mathrm{Fe}$ & wt $\%$ & ICP-ES & 7.12E-02 & 7E-04 & $<1.39 E-03$ & $6.73 \mathrm{E}-03$ & $1.74 \mathrm{E}-03$ & 0.8 \\
\hline $\mathrm{Gd}$ & wt $\%$ & ICP-ES & $<1.26 E-03$ & - & $<1.70 E-03$ & $<1.31 E-03$ & $<1.28 E-03$ & -- \\
\hline $\mathrm{Hg}$ & wt $\%$ & CV AA & 1.9E-02 & 1E-03 & -- & $3.1 \mathrm{E}-03$ & $3.5 \mathrm{E}-03$ & 6 \\
\hline $\mathrm{La}$ & wt $\%$ & ICP-ES & $<9.33 E-04$ & -- & $<1.26 E-03$ & $<9.74 E-04$ & $<9.48 E-04$ & -- \\
\hline $\mathrm{Li}$ & wt $\%$ & ICP-ES & $<3.96 E-03$ & -- & $<5.37 E-03$ & $<4.14 E-03$ & $</=4.08 \mathrm{E}-03$ & -- \\
\hline $\mathrm{Mg}$ & wt $\%$ & ICP-ES & $<2.89 E-03$ & -- & $<3.91 E-03$ & $<3.02 E-03$ & $<2.94 E-03$ & -- \\
\hline $\mathrm{Mn}$ & wt $\%$ & ICP-ES & 5.33E-03 & $9.8 \mathrm{E}-05$ & $<1.39 E-03$ & $<1.07 E-03$ & $<1.04 E-03$ & $<8$ \\
\hline Mo & wt $\%$ & ICP-ES & $<9.51 E-03$ & -- & $<1.29 E-02$ & $<9.93 E-03$ & $<9.67 E-03$ & -- \\
\hline $\mathrm{Ni}$ & wt $\%$ & ICP-ES & $</=6.7 E-03$ & $5.6 \mathrm{E}-03$ & $<4.73 E-03$ & $<3.65 E-03$ & $<3.56 E-03$ & -- \\
\hline $\mathrm{Pb}$ & wt $\%$ & ICP-ES & $<1.15 E-02$ & -- & $<1.55 E-02$ & $<1.20 E-02$ & $<1.17 E-02$ & -- \\
\hline $\mathrm{Sb}$ & wt $\%$ & ICP-ES & $<7.04 E-03$ & -- & $<9.53 E-03$ & $<7.35 E-03$ & $<7.16 E-03$ & -- \\
\hline $\mathrm{Si}$ & wt $\%$ & ICP-ES & $2.31 \mathrm{E}-02$ & $4.8 \mathrm{E}-03$ & $1.02 \mathrm{E}-02$ & $6.03 E-02$ & 4.85E-02 & -- \\
\hline $\mathrm{Se}$ & wt $\%$ & AA & $<2.3 E-04$ & -- & -- & $<2.4 E-04$ & $<2.4 E-04$ & -- \\
\hline Sn & wt $\%$ & ICP-ES & $<1.14 E-02$ & -- & $<1.55 E-02$ & $<1.19 E-02$ & $<1.16 E-02$ & -- \\
\hline $\mathrm{Sr}$ & wt $\%$ & ICP-ES & $<4.66 E-03$ & -- & $<6.31 E-03$ & $<4.87 E-03$ & $<4.74 E-03$ & -- \\
\hline $\mathrm{Ti}$ & wt $\%$ & ICP-ES & $<2.80 E-04$ & -- & $<3.79 E-04$ & $<2.92 E-04$ & $<2.84 E-04$ & -- \\
\hline $\mathrm{V}$ & wt $\%$ & ICP-ES & $<5.13 E-04$ & -- & $<6.94 E-04$ & $<5.36 E-04$ & $<5.22 E-04$ & -- \\
\hline $\mathrm{Zn}$ & wt $\%$ & ICP-ES & $<2.56 E-03$ & -- & $<3.47 E-03$ & $<2.68 E-03$ & $<2.61 E-03$ & -- \\
\hline $\mathrm{Zr}$ & wt $\%$ & ICP-ES & $<5.59 E-04$ & -- & $<7.58 E-04$ & $<5.84 E-04$ & $<5.69 E-04$ & -- \\
\hline
\end{tabular}


Table 5: Comparison of components in Tank 38H liquids, including direct measurement of filtered free liquid (FL) and supernatant liquid (SL), and projections for dissolved salts (containing residual insoluble solids) from undrained (UDS) and drained (DDS) saltcake

\begin{tabular}{|c|c|c|c|c|c|c|c|c|}
\hline Analyte & Units & Method & $\mathrm{FL}$ & $\mathrm{SL}$ & UDS-0 & DDS-25* & DDS-50* & DDS-100* \\
\hline $\mathrm{Na}^{+}$ & $M$ & ICP-ES & 10.73 & 10.53 & 6.00 & 6.00 & 6.00 & 6.00 \\
\hline $\mathrm{NO}_{3}{ }^{-}$ & $M$ & IC & 2.08 & 2.20 & 4.06 & 4.24 & 4.45 & 4.95 \\
\hline $\mathrm{NO}_{2}$ & $M$ & IC & 1.77 & 1.80 & 0.239 & 0.192 & 0.139 & 0.0077 \\
\hline $\mathrm{OH}^{-}$ & $M$ & Wet Chem. & 5.54 & 5.03 & 0.70 & 0.55 & 0.38 & 0 \\
\hline $\mathrm{OH}$ & $\mathrm{M}$ & Calcutated & 6.21 & 6.53 & 1.07 & 0.92 & 0.75 & 0.33 \\
\hline $\mathrm{AlO}_{2}$ & $M$ & ICP-ES & 0.16 & 0.165 & 0.031 & 0.028 & 0.024 & 0.013 \\
\hline $\mathrm{CO}_{3}{ }^{2-}$ & $M$ & TIC/TOC & 0.29 & 0.25 & 0.35 & 0.36 & 0.37 & 0.41 \\
\hline $\mathrm{SO}_{4}{ }^{2-}$ & $M$ & IC & 0.024 & 0.018 & 0.101 & 0.107 & 0.113 & 0.128 \\
\hline $\mathrm{SO}_{4}{ }^{2-}$ & $M$ & ICP-ES & 0.070 & 0.052 & 0.128 & 0.133 & 0.139 & 0.155 \\
\hline $\mathrm{PO}_{4}{ }^{3-}$ & $M$ & IC & 0.012 & 0.012 & 0.0012 & 0.00081 & 0.00042 & 0 \\
\hline $\mathrm{PO}_{4}{ }^{3-}$ & $\mathrm{M}$ & ICP-ES & 0.015 & 0.013 & -- & -- & -- & -- \\
\hline $\mathrm{Cl}^{-}$ & $M$ & IC & $<=0.0049$ & 0.0040 & $<0.0015$ & $<0.0014$ & $<0.0013$ & $<0.0011$ \\
\hline $\mathrm{F}$ & $\mathrm{M}$ & IC & $<0.0092$ & 0.0037 & 0.0112 & 0.0118 & 0.0125 & 0.0141 \\
\hline $\mathrm{C}_{2} \mathrm{O}_{4}{ }^{2-}$ & $M$ & IC & $<0.0099$ & 0.0024 & 0.032 & 0.033 & 0.036 & 0.041 \\
\hline $\mathrm{CHO}_{2}$ & $\mathrm{M}$ & IC & 0.048 & 0.047 & 0.0075 & 0.0063 & 0.0049 & 0.0016 \\
\hline $\mathrm{K}^{+}$ & $\mathrm{M}$ & $A A$ & -- & 0.024 & 0.0033 & 0.0027 & 0.0020 & 0.0002 \\
\hline $\mathrm{K}^{+}$ & $\mathrm{M}$ & AA & -- & $<0.168$ & $<0.069$ & $<0.068$ & $<0.066$ & $<0.062$ \\
\hline $\mathrm{Cs}^{+}$ & $\mathrm{mM}$ & ICP-MS/RdChm & 0.053 & 0.042 & 0.0069 & 0.0055 & 0.0038 & 0 \\
\hline${ }^{137} \mathrm{Cs}$ & $\mathrm{pCi} / \mathrm{mL}$ & Rad. Chem. & $1.93 \mathrm{E}+08$ & $1.70 \mathrm{E}+08$ & $2.27 \mathrm{E}+07$ & $1.74 \mathrm{E}+07$ & $1.13 \mathrm{E}+07$ & 0 \\
\hline${ }^{238} \mathrm{Pu}$ & $\mathrm{pCi} / \mathrm{mL}$ & Rad. Chem. & $5.78 \mathrm{E}+03$ & $2.30 \mathrm{E}+04$ & $2.21 \mathrm{E}+06$ & $2.35 \mathrm{E}+06$ & $2.51 \mathrm{E}+06$ & $2.89 \mathrm{E}+06$ \\
\hline sludge & $\mathrm{mg} / \mathrm{L}$ & ICP-ES & -- & -- & 942 & 989 & 1042 & 1173 \\
\hline \multicolumn{3}{|c|}{ g salt / L 6M Na ${ }^{+}$} & -- & -- & 610 & 598 & 585 & 552 \\
\hline
\end{tabular}

* Drained Dissolved Salt solutions calculated by removing a percentage (25\%, $50 \%$, or $100 \%)$ of the IL/FL/SL.

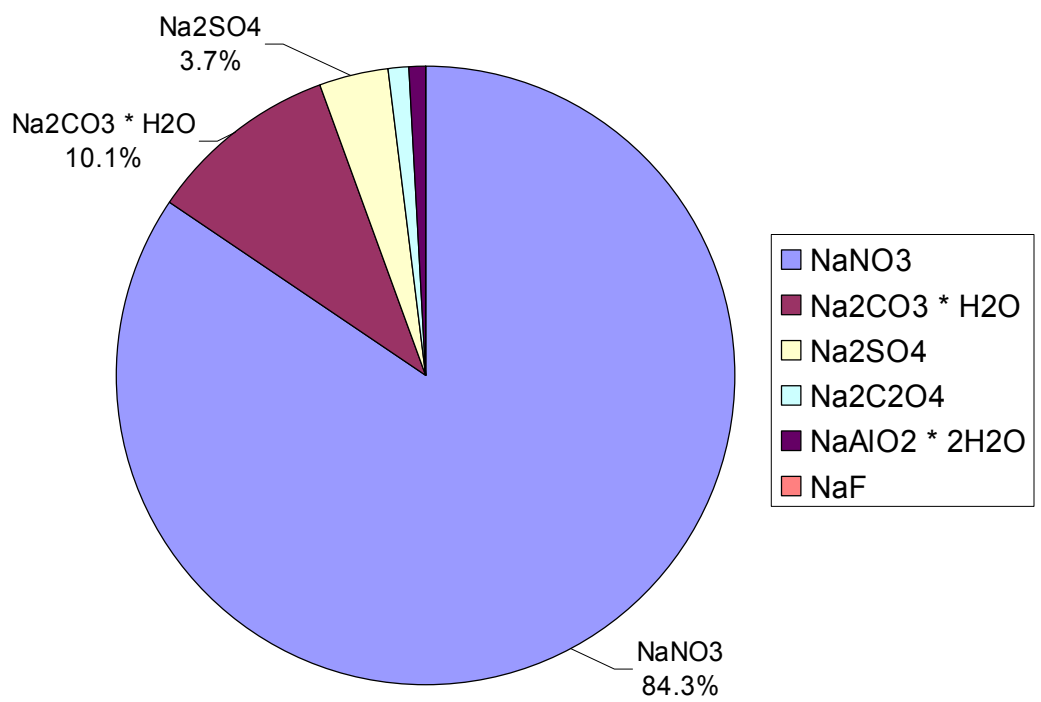

Figure 7: Likely major components of Tank $38 \mathrm{H}$ salt solids, normalized to $100 \mathrm{wt} \%$ 
Table 6: Comparison of HTF-E-03-114 with previous Tank $38 \mathrm{H}$ saltcake surface samples

\begin{tabular}{|c|c|c|c|c|c|}
\hline \multicolumn{2}{|l|}{ Sample } & HTF-003 & no name & $\begin{array}{c}\text { HTF-Tk38- } \\
088,089\end{array}$ & $\begin{array}{l}\text { HTF-E- } \\
03-114\end{array}$ \\
\hline \multicolumn{2}{|l|}{ Date } & 1996 & July 2000 & July 2001 & Sept. 2003 \\
\hline \multicolumn{2}{|l|}{ Reference } & 4 & 6 & 7 & this report \\
\hline Water & $w t \%$ & -- & 22.1 & -- & 16.8 \\
\hline${ }^{14} \mathrm{C}$ & $\mathrm{pCi} / \mathrm{g}$ & -- & -- & -- & $5.61 \mathrm{E}+03$ \\
\hline${ }^{60} \mathrm{Co}$ & $\mathrm{pCi} / \mathrm{g}$ & -- & $9.68 \mathrm{E}+03$ & -- & -- \\
\hline${ }^{90} \mathrm{Sr}$ & $\mathrm{pCi} / \mathrm{g}$ & -- & $2.45 \mathrm{E}+07$ & $8.83 E+06$ & $5.24 \mathrm{E}+06$ \\
\hline${ }^{99} \mathrm{Tc}$ & $\mathrm{pCi} / \mathrm{g}$ & -- & -- & -- & $1.51 \mathrm{E}+04$ \\
\hline${ }^{125} \mathrm{Sb}$ & $\mathrm{pCi} / \mathrm{g}$ & -- & $4.59 \mathrm{E}+05$ & $3.73 E+05$ & -- \\
\hline${ }^{134} \mathrm{Cs}$ & $\mathrm{pCi} / \mathrm{g}$ & -- & $2.33 E+07$ & -- & -- \\
\hline${ }^{135} \mathrm{Cs}$ & $\mathrm{pCi} / \mathrm{g}$ & -- & -- & -- & $1.79 E+02$ \\
\hline${ }^{137} \mathrm{Cs}$ & $\mathrm{pCi} / \mathrm{g}$ & -- & $3.44 \mathrm{E}+07$ & $2.80 \mathrm{E}+07$ & $3.72 E+07$ \\
\hline${ }^{232} \mathrm{Th}$ & $\mathrm{pCi} / \mathrm{g}$ & -- & $1.29 E+00$ & $2.56 \mathrm{E}-01$ & 2.51E-01 \\
\hline${ }^{233} U$ & $\mathrm{pCi} / \mathrm{g}$ & -- & $<2.0 E+02$ & $4.92 \mathrm{E}+03$ & $<7.7 E+02$ \\
\hline${ }^{234} U$ & $\mathrm{pCi} / \mathrm{g}$ & $1.87 \mathrm{E}+03$ & $5.03 E+04$ & $4.54 \mathrm{E}+04$ & $6.56 \mathrm{E}+03$ \\
\hline${ }^{235} \mathrm{U}$ & $\mathrm{pCi} / \mathrm{g}$ & $2.38 \mathrm{E}-01$ & $3.26 \mathrm{E}+01$ & $3.29 \mathrm{E}+01$ & $7.21 \mathrm{E}+00$ \\
\hline${ }^{236} \mathrm{U}$ & $\mathrm{pCi} / \mathrm{g}$ & $3.23 E+00$ & $3.07 \mathrm{E}+02$ & $2.65 \mathrm{E}+02$ & $3.40 \mathrm{E}+01$ \\
\hline${ }^{237} \mathrm{~Np}$ & $\mathrm{pCi} / \mathrm{g}$ & $7.05 E+01$ & $5.05 E+03$ & $4.26 \mathrm{E}+03$ & $3.56 \mathrm{E}+02$ \\
\hline${ }^{238} \mathrm{U}$ & $\mathrm{pCi} / \mathrm{g}$ & $1.14 \mathrm{E}+00$ & $3.43 E+02$ & $2.92 \mathrm{E}+02$ & $1.55 \mathrm{E}+02$ \\
\hline${ }^{238} \mathrm{Pu}$ & $\mathrm{pCi} / \mathrm{g}$ & -- & $1.42 E+07$ & $1.19 \mathrm{E}+07$ & $3.62 E+06$ \\
\hline${ }^{239 / 240} \mathrm{Pu}$ & $\mathrm{pCi} / \mathrm{g}$ & -- & $2.64 \mathrm{E}+05$ & $2.19 \mathrm{E}+05$ & $6.46 E+04$ \\
\hline${ }^{239} \mathrm{Pu}$ & $\mathrm{pCi} / \mathrm{g}$ & $4.85 E+04$ & $1.87 \mathrm{E}+05$ & $9.24 \mathrm{E}+04$ & $3.36 \mathrm{E}+04$ \\
\hline${ }^{240} \mathrm{Pu}$ & $\mathrm{pCi} / \mathrm{g}$ & $1.34 \mathrm{E}+04$ & $2.08 \mathrm{E}+05$ & $1.54 \mathrm{E}+05$ & $3.35 \mathrm{E}+04$ \\
\hline${ }^{241} \mathrm{Pu}$ & $\mathrm{pCi} / \mathrm{g}$ & $8.24 \mathrm{E}+05$ & $9.23 \mathrm{E}+06$ & $9.14 \mathrm{E}+06$ & $<8.16 E+06$ \\
\hline${ }^{241} \mathrm{Am}$ & $\mathrm{pCi} / \mathrm{g}$ & -- & $2.05 \mathrm{E}+05$ & -- & $<2.72 E+05$ \\
\hline${ }^{242} \mathrm{Pu}$ & $\mathrm{pCi} / \mathrm{g}$ & $1.57 \mathrm{E}+01$ & $9.13 E+03$ & $8.44 \mathrm{E}+03$ & $7.26 \mathrm{E}+02$ \\
\hline Gross Alpha & $\mathrm{pCi} / \mathrm{g}$ & -- & $1.76 \mathrm{E}+07$ & -- & -- \\
\hline Gross Beta & $\mathrm{pCi} / \mathrm{g}$ & - & $9.46 \mathrm{E}+07$ & $7.93 \mathrm{E}+07$ & -- \\
\hline Total U & wt $\%$ & 3.90E-04 & $1.05 \mathrm{E}-01$ & 8.96E-02 & $4.66 \mathrm{E}-02$ \\
\hline${ }^{235} \mathrm{U}$ Enrichment & wt \% & $2.90 \%$ & $1.44 \%$ & $1.70 \%$ & $0.72 \%$ \\
\hline $\mathrm{Na}^{+}$ & wt $\%$ & $3.00 \mathrm{E}+01$ & $2.98 \mathrm{E}+01$ & $3.06 \mathrm{E}+01$ & $2.26 \mathrm{E}+01$ \\
\hline $\mathrm{AlO}_{2}^{-}$ & wt $\%$ & 4.59E-01 & 4.39E-01 & 2.67E-01 & $3.02 \mathrm{E}-01$ \\
\hline $\mathrm{PO}_{4}{ }^{3-}$ & wt $\%$ & 5.83E-02 & $6.01 \mathrm{E}-02$ & $<4.28 E-02$ & $1.80 \mathrm{E}-02$ \\
\hline $\mathrm{Ca}$ & wt $\%$ & $5.40 \mathrm{E}-03$ & 6.08E-02 & 2.07E-02 & $<2.11 E-02$ \\
\hline $\mathrm{Cr}$ & wt $\%$ & 1.20E-02 & 7.06E-03 & $<6.10 E-03$ & $4.85 \mathrm{E}-03$ \\
\hline $\mathrm{Fe}$ & wt \% & 2.60E-02 & 3.17E-01 & 7.50E-02 & $7.12 \mathrm{E}-02$ \\
\hline $\mathrm{Mg}$ & wt $\%$ & $1.30 \mathrm{E}-03$ & $1.60 \mathrm{E}-02$ & 4.91E-03 & $<2.89 E-03$ \\
\hline $\mathrm{Mn}$ & wt \% & 3.70E-02 & 2.82E-02 & 4.10E-03 & 5.33E-03 \\
\hline $\mathrm{Si}$ & wt \% & -- & 1.35E-01 & 1.07E-02 & 2.31E-02 \\
\hline
\end{tabular}




\section{Microscopy}

The X-ray diffraction pattern for the filter containing the washed insoluble solids removed from the free liquid in saltcake core sample HTF-E-03-114 is shown in Figure 8. The salt components sodium carbonate monohydrate, sodium nitrate, and sodium nitrite were seen in the solids. Two sodium aluminosilicate compounds, cancrinite and zeolite $\mathrm{Y}$, were also identified as components of the insoluble solids. With the history of sodium aluminosilicate buildup in the $2 \mathrm{H}$-evaporator pot and gravity drain line, it is not surprising that aluminosilicates are noted in the insoluble solids near the surface of the saltcake in the drop tank (Tank $38 \mathrm{H})$.

Figure 9 contains several of the SEM images for the filtered insoluble solids from the Tank $38 \mathrm{H}$ free liquid sample. The remainder of the SEM images, along with the EDS graphs are contained in the appendix in Figure 10 through Figure 12. The top and middle micrographs in Figure 9 are the same portions of the solids taken at different magnifications. The three locations of the solids that were investigated yielded a large variety of morphologies and relatively large particle sizes. The globular solids with noticeable pores were seen by EDS to be composed primarily of aluminum. The morphology, however, is consistent with the radial ball structure previously noted for some of the sodium aluminosilicate phase, sodalite. ${ }^{12,13,14,15}$ The needle-like structure seen in the lower photo are consistent with transitional sodium aluminosilicate phases. Some needles were small (less than 10 micron), while many were greater than 100 micron in length. The Au and Pd in the EDS spectra are from the coating applied during sample preparation. Although the solids were very dark in color (Figure 4) only trace amounts of transition metals ( $\mathrm{Fe}, \mathrm{Ni}$ ) were observed in the EDS spectra.

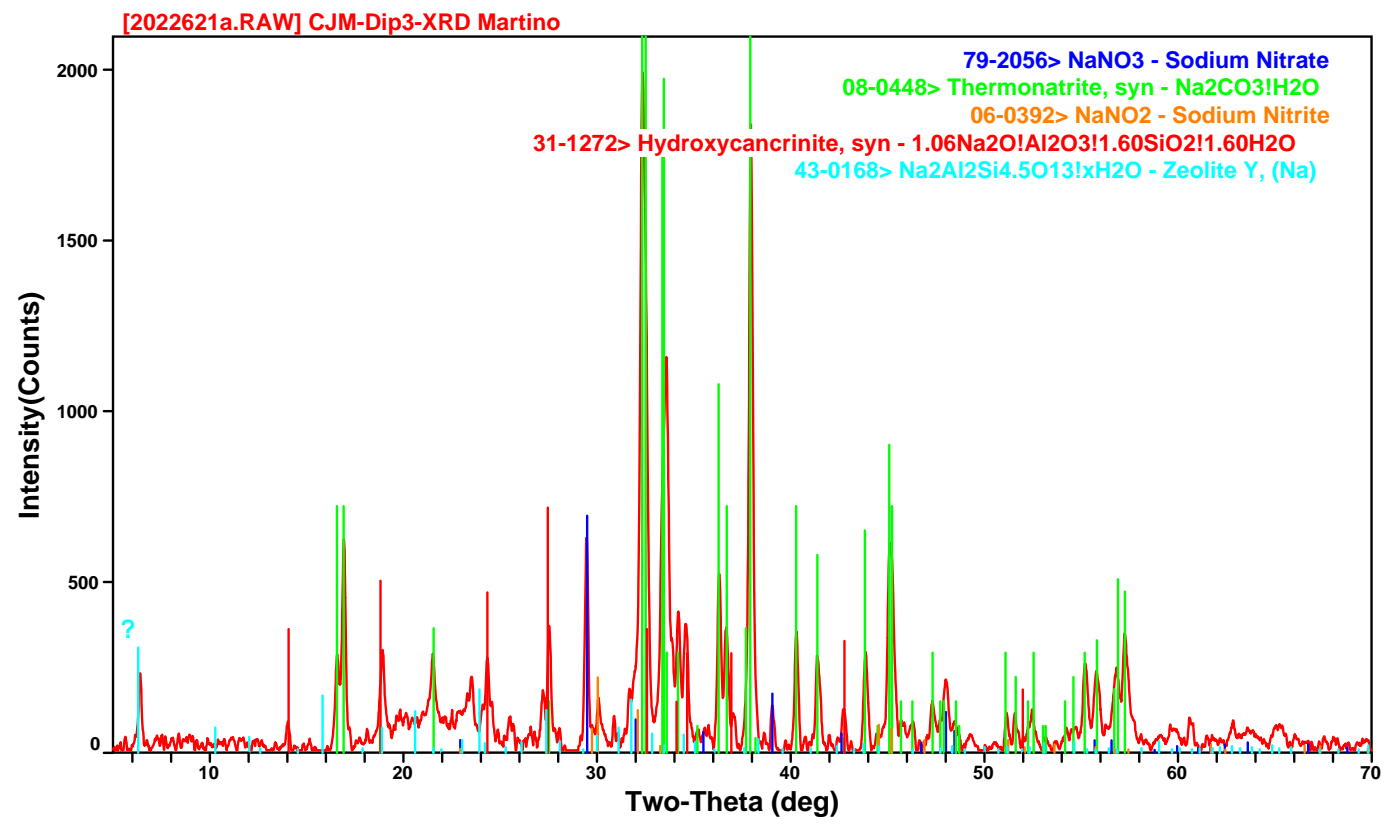

Figure 8: XRD of insoluble solids filtered from the free liquid contained in the Tank 38H saltcake sample 
WSRC-TR-2004-00129

Revision 0
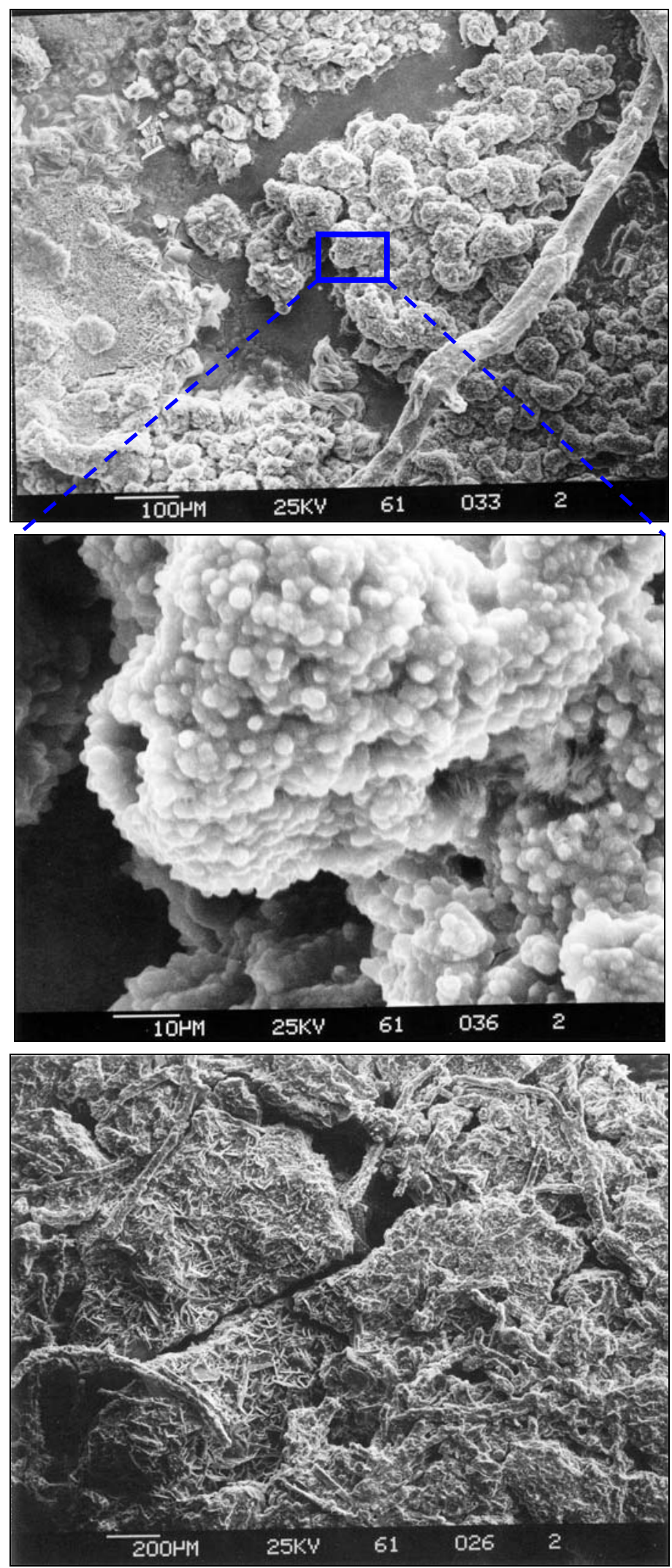

Figure 9: SEM images of insoluble solids filtered from the free liquid contained in the Tank $38 \mathrm{H}$ saltcake sample 


\section{$\underline{\text { Hydraulic Properties }}$}

The interstitial liquid content of the undrained saltcake contained in HTF-E-03-114, not including the free liquid, was approximated at $42 \mathrm{vol} \%$. Thus, the porosity of the saltcake is $42 \mathrm{vol} \%$ if a pore saturation of $100 \mathrm{vol} \%$ is assumed.

Because the sample was removed from the tube during initial sample preparation, no tests were performed to determine the permeability of the saltcake.

\section{Conclusions}

The core sample HTF-E-03-114 contained approximately 4 inches of saltcake, which was soupy and brown with white chunks, and contained less than $15 \mathrm{~mL}$ of cloudy free liquid. The undrained bulk saltcake had a water content of $16.8 \mathrm{wt} \%$ and a bulk density that was approximated at full saturation to be $1.94 \mathrm{~g} / \mathrm{cm}^{3}$. The ${ }^{137} \mathrm{Cs}$ activity of the bulk saltcake in sample HTF-E-03-114 was $3.72 \mathrm{E}+7 \mathrm{pCi} / \mathrm{g}$, which corresponds to approximately $0.3 \mathrm{Ci}$ per gallon of saltcake. The ${ }^{238} \mathrm{Pu}$ activity of the bulk saltcake was $3.62 \mathrm{E}+6 \mathrm{pCi} / \mathrm{g}$.

The filtered free liquid in sample HTF-E-03-114 had a density of $1.430 \mathrm{~g} / \mathrm{cm}^{3}$, a ${ }^{137} \mathrm{Cs}$ activity of 0.73 $\mathrm{Ci} /$ gal., and a ${ }^{238} \mathrm{Pu}$ activity of $5.78 \mathrm{E}+3 \mathrm{pCi} / \mathrm{mL}$. The solids filtered from the HTF-E-03-114 free liquid were composed of salts (sodium nitrate and sodium carbonate monohydrate) and sodium aluminosilicates.

The Tank $38 \mathrm{H}$ supernate samples (HTF-E-03-122 and 123) had a density of $1.45 \mathrm{~g} / \mathrm{cm}^{3}$, a ${ }^{137} \mathrm{Cs}$ activity of $0.65 \mathrm{Ci} / \mathrm{gal}$, a ${ }^{238} \mathrm{Pu}$ activity of $2.2 \mathrm{E} 4 \mathrm{pCi} / \mathrm{mL}$, and contained no visible insoluble solids. The viscosity of a composite of supernate samples HTF-E-03-122 and 123 was determined at $25^{\circ} \mathrm{C}, 35$ ${ }^{\circ} \mathrm{C}$, and $50{ }^{\circ} \mathrm{C}$ to be $12.1 \mathrm{cP}, 8.1 \mathrm{cP}$, and $5.1 \mathrm{cP}$, respectively. An exponential correlation for the Tank $38 \mathrm{H}$ supernate viscosity was formulated for use over this temperature range.

Several components, including cesium, nitrite, hydroxide, phosphate, formate, and potassium, were measured to be partitioned nearly completely into the saltcake interstitial liquid (within experimental uncertainty). Although the plutonium, uranium, neptunium, and strontium activities in the Tank $38 \mathrm{H}$ saltcake core sample are high compared with recent Tank $41 \mathrm{H}$ samples, they are low compared with previous saltcake samples from Tank $38 \mathrm{H}$ pulled in July 2000 and July 2001 . The ${ }^{137} \mathrm{Cs}$ of the Tank $38 \mathrm{H}$ saltcake sample is comparable with the previous Tank $38 \mathrm{H}$ saltcake samples.

\section{Quality Assurance}

This work satisfies the requirements of the original task technical and quality assurance plan. ${ }^{16}$ Laboratory Notebooks WSRC-NB-2003-00198, WSRC-NB-2003-00199, and various ADS notebooks contain the experimental data.

\section{Acknowledgements}

The authors would like to thank the following for their important contributions to this project: John Sessions, Glen Johnson, and Dennis Conrad of the Closure Business Unit; Nancy Gregory and Sharon Smith in SRTC Waste Processing Technology; Monica Jenkins, Mona Galloway, Monica Miller, Rita Sullivan, Carolyn Conley, Dave Keel, Ron Blessing and many others in SRTC Shielded Cells Operations; Tom Nance and Dan Krementz of SRTC Remote Specialty Equipment; Leigh Brown, Dave Diprete, Ceci Diprete, Theresa Eddy, June Hart, Damon Click, Bill Boyce, Mira Malek, Chuck Coleman, Beverly Burch, John Young, Amy Ekechukwu, Robert Ray, Steve Crump, Michael 
Whitaker, Art Jurgensen, Dave Missimer, Wilson Smith, and many technicians of SRTC Analytical Development.

\section{References}

1 J. R. Sessions, "Saltcake Characterization to Support Closure Activities," CBU-SPT-2003-00126, Rev. 0, July 17, 2003.

2 D. T. Conrad, "LCS Sampling and Analysis Plan for Process Validation," CBU-SPT-2003-00164, Rev. 0, September 9, 2003.

${ }^{3}$ C. M. Jantzen, J. E. Laurinat, and K. G. Brown, "Thermodynamic Modeling of the SRS Evaporators: Part I. The 2H and 2F Systems (U)," WSRC-TR-2000-00293, Rev. 1, April 4, 2002.

${ }^{4}$ D. T. Hobbs, "Final Report on the Analytical Results for Tank Farm Samples in Support of Salt Dissolution Evaluations," WSRC-TR-96-0410, Rev. 0, December 12, 1996.

${ }^{5}$ W. R. Wilmarth, "Analytical Results from Tank 38H Criticality Sample HTF-093," WSRC-RP-9800725, Rev. 0, July 31, 1998.

${ }^{6}$ R. F. Swingle, "Characterization of the Tank $38 \mathrm{H}$ Variable Depth and Core Samples," WSRC-RP2001-00574, Rev. 0, May 2, 2001.

${ }^{7}$ L. N. Oji and R. F. Swingle, "Characterization of Tank 38H Core Samples," WSRC-TR-2001-00516, Rev. 0, October 31, 2001.

${ }^{8}$ C. J. Martino and M. R. Poirier, "Tank 31H Saltcake Dissolution Tests," WSRC-TR-2002-00388, Rev. 0, February 27, 2003.

${ }^{9}$ P. D. d'Entremont and J. M. Gillam, "Results if Tank 43H Samples for Uranium-235 Enrichment," WSRC-TR-2001-00470, Rev. 0, October 2, 2001.

${ }^{10}$ P. D. d'Entremont, WSRC-TR-2001-00308, Rev. 0.

${ }^{11}$ C. J. Martino and R. L. Nichols, "Tank 41H Drained Saltcake Core Sample Analysis (HTF-E-03-033 - HTF-E-03-035)," WSRC-TR-2003-00227, Rev. 0, December 16, 2003.

${ }^{12}$ L. O. Dworjanyn, "Simulated Aluminosilicate Formation and 2H-Evaporator Scaling (U)," WSRCRP-2001-00779, August 2001.

${ }^{13}$ J. Addai-Mensah, J. Li, M. Zbik, and S. W. Rosencrance, "The Chemistry, Crystallization, Physiochemical Properties and Behavior of Sodium Aluminosilicate Solid Phases: Final Report," WSRC-MS-2002-00907, November 20, 2002.

${ }^{14}$ M. Z. Hu, D. W. DePaoli, and D. T. Bostick, "Dynamic Particle Growth Testing: Phase I Studies," ORNL/TM-2001/100, June 18, 2001.

${ }^{15}$ A. J. Mattis, C. H. Mattis, and R. D. Hunt, "Investigation into the Control and Kinetics of Aluminosilicate Formation on Stainless Steel Surfaces at $100^{\circ} \mathrm{C}$," ORNL/TM-2002/47, April 2002.

${ }^{16}$ R. L. Nichols and C. J. Martino, "Task Technical and Quality Assurance Plan for the Characterization of Drained Low-Curie Saltcake," WSRC-RP-2003-00319, Rev. 1, June 3, 2003. 
WSRC-TR-2004-00129

Revision 0

\section{Appendix}

Table 7: Tank 38H Undrained Bulk Saltcake ICP-ES results (g/100g)

\begin{tabular}{|c|c|c|}
\hline Tank $38 \mathrm{H}$ & \multicolumn{2}{|c|}{ HTF-E-03-114 } \\
\hline$(g / 100 g)$ & Average & St. Dev. \\
\hline $\mathrm{Ag}$ & $<6.99 E-04$ & -- \\
\hline $\mathrm{Al}$ & $1.38 \mathrm{E}-01$ & $3 E-03$ \\
\hline B & $<7.55 E-02$ & -- \\
\hline $\mathrm{Ba}$ & $<6.99 E-04$ & -- \\
\hline $\mathrm{Ca}$ & $<2.11 E-02$ & -- \\
\hline $\mathrm{Cd}$ & $<9.33 E-04$ & -- \\
\hline $\mathrm{Ce}$ & $<1.16 E-02$ & -- \\
\hline $\mathrm{Cr}$ & 4.85E-03 & $7.8 \mathrm{E}-04$ \\
\hline $\mathrm{Cu}$ & $</=3.3 E-02$ & $5.4 \mathrm{E}-02$ \\
\hline $\mathrm{Fe}$ & 7.12E-02 & 7E-04 \\
\hline $\mathrm{Gd}$ & $<1.26 E-03$ & -- \\
\hline $\mathrm{K}$ & $<4.44 E-01$ & -- \\
\hline $\mathrm{La}$ & $<9.33 E-04$ & -- \\
\hline $\mathrm{Li}$ & $<3.96 E-03$ & -- \\
\hline $\mathrm{Mg}$ & $<2.89 E-03$ & -- \\
\hline $\mathrm{Mn}$ & 5.33E-03 & $9.8 \mathrm{E}-05$ \\
\hline Mo & $<9.51 E-03$ & -- \\
\hline $\mathrm{Na}$ & $2.26 \mathrm{E}+01$ & $1.0 \mathrm{E}+00$ \\
\hline $\mathrm{Ni}$ & $</=6.7 E-03$ & $5.6 \mathrm{E}-03$ \\
\hline$P$ & $<2.26 E-02$ & -- \\
\hline $\mathrm{Pb}$ & $<1.15 E-02$ & -- \\
\hline $\mathrm{S}$ & $6.70 \mathrm{E}-01$ & 7.6E-02 \\
\hline $\mathrm{Sb}$ & $<7.04 E-03$ & -- \\
\hline $\mathrm{Si}$ & 2.31E-02 & $4.8 \mathrm{E}-03$ \\
\hline$S n$ & $<1.14 E-02$ & -- \\
\hline $\mathrm{Sr}$ & $<4.66 E-03$ & -- \\
\hline $\mathrm{Ti}$ & $<2.80 E-04$ & -- \\
\hline V & $<5.13 E-04$ & -- \\
\hline $\mathrm{Zn}$ & $<2.56 E-03$ & -- \\
\hline $\mathrm{Zr}$ & $<5.59 E-04$ & -- \\
\hline
\end{tabular}


Table 8: Tank 38H Undrained Bulk Saltcake rad. chem. results (pCi/g)

\begin{tabular}{|c|rc|}
\hline Tank 38H & \multicolumn{2}{|c|}{ HTF-E-03-114 } \\
\hline (pCi/g) & Average & St. Dev. \\
\hline${ }^{14} \mathrm{C}$ & $5.6 \mathrm{E}+03$ & -- \\
\hline${ }^{90} \mathrm{Sr}$ & $5.24 \mathrm{E}+06$ & $1.84 \mathrm{E}+06$ \\
\hline${ }^{137} \mathrm{Cs}$ & $3.72 \mathrm{E}+07$ & $2.5 \mathrm{E}+06$ \\
\hline${ }^{238} \mathrm{Pu}$ & $3.62 \mathrm{E}+06$ & $3.3 \mathrm{E}+05$ \\
\hline${ }^{239 / 240} \mathrm{Pu}$ & $6.46 \mathrm{E}+04$ & $2.84 \mathrm{E}+04$ \\
\hline
\end{tabular}

Table 9: Tank 38H Undrained Bulk Saltcake AA results $(\mathrm{g} / 100 \mathrm{~g})$

\begin{tabular}{|c|rc|}
\hline Tank 38H & \multicolumn{2}{|c|}{ HTF-E-03-114 } \\
\hline$(\mathrm{g} / 100 \mathrm{~g})$ & Average & St. Dev. \\
\hline $\mathrm{As}$ & $<2.3 \mathrm{E}-04$ & -- \\
\hline $\mathrm{K}$ & $2.1 \mathrm{E}-02$ & $2 \mathrm{E}-03$ \\
\hline $\mathrm{Se}$ & $<2.3 \mathrm{E}-04$ & -- \\
\hline $\mathrm{Hg}$ & $1.9 \mathrm{E}-02$ & $1 \mathrm{E}-03$ \\
\hline
\end{tabular}

Table 10: Tank 38H Undrained Bulk Saltcake IC anions results (g/100g)

\begin{tabular}{|c|rr|}
\hline Tank 38H & \multicolumn{2}{|c|}{ HTF-E-03-114 } \\
\hline$(\mathrm{g} / 100 \mathrm{~g})$ & \multicolumn{1}{|c|}{ Average } & St. Dev. \\
\hline $\mathrm{NO}_{3}{ }^{-}$ & $4.12 \mathrm{E}+01$ & $5.2 \mathrm{E}+00$ \\
\hline $\mathrm{NO}_{2}{ }^{-}$ & $1.80 \mathrm{E}+00$ & $6 \mathrm{E}-02$ \\
\hline $\mathrm{SO}_{4}{ }^{2-}$ & $1.59 \mathrm{E}+00$ & $1.5 \mathrm{E}-01$ \\
\hline $\mathrm{PO}_{4}{ }^{3-}$ & $1.80 \mathrm{E}-02$ & $3.1 \mathrm{E}-03$ \\
\hline $\mathrm{Cl}^{-}$ & $<8.68 \mathrm{E}-03$ & -- \\
\hline $\mathrm{F}^{-}$ & $3.50 \mathrm{E}-02$ & $2.8 \mathrm{E}-03$ \\
\hline $\mathrm{C}_{2} \mathrm{O}_{4}{ }^{2-}$ & $4.56 \mathrm{E}-01$ & $1.4 \mathrm{E}-02$ \\
\hline $\mathrm{CHO}_{2}{ }^{-}$ & $5.50 \mathrm{E}-02$ & $1.58 \mathrm{E}-02$ \\
\hline $\mathrm{Free} \mathrm{OH}^{-}$ & $1.96 \mathrm{E}+00$ & $4.4 \mathrm{E}-01$ \\
\hline $\mathrm{CO}_{3}{ }^{2-}$ & $3.42 \mathrm{E}+00$ & $9.7 \mathrm{E}-01$ \\
\hline $\mathrm{TOC}$ & $1.3 \mathrm{E}+00$ & $3 \mathrm{E}-01$ \\
\hline
\end{tabular}


WSRC-TR-2004-00129

Revision 0

Table 11: Tank 38H Undrained Bulk Saltcake ICP-MS results (g/100g)

\begin{tabular}{|c|cc|}
\hline Tank 38H & \multicolumn{3}{|c|}{ HTF-E-03-114 } \\
\hline$(\mathrm{g} / 100 \mathrm{~g})$ & Average & St. Dev. \\
\hline Mass 59 & $2.7 \mathrm{E}-05$ & $1.0 \mathrm{E}-05$ \\
\hline Mass 88 & $3.2 \mathrm{E}-05$ & $2 \mathrm{E}-06$ \\
\hline Mass 99 & $8.9 \mathrm{E}-05$ & $2.2 \mathrm{E}-05$ \\
\hline Mass 101 & $3.4 \mathrm{E}-05$ & $2 \mathrm{E}-05$ \\
\hline Mass 133 & $1.10 \mathrm{E}-04$ & $7 \mathrm{E}-06$ \\
\hline Mass 135 & \multicolumn{1}{|c}{$1.6 \mathrm{E}-05$} & $2 \mathrm{E}-06$ \\
\hline Mass 137 & $8.2 \mathrm{E}-05$ & $6 \mathrm{E}-06$ \\
\hline Mass 138 & $5.7 \mathrm{E}-05$ & $4.3 \mathrm{E}-06$ \\
\hline Mass 230 & $<7.9 \mathrm{E}-06$ & -- \\
\hline Mass 231 & $<7.9 \mathrm{E}-06$ & -- \\
\hline Mass 232 & $2.3 \mathrm{E}-04$ & $2 \mathrm{E}-05$ \\
\hline Mass 233 & $<7.9 \mathrm{E}-06$ & -- \\
\hline Mass 234 & $1.1 \mathrm{E}-04$ & $7 \mathrm{E}-06$ \\
\hline Mass 235 & $3.3 \mathrm{E}-04$ & $5 \mathrm{E}-05$ \\
\hline Mass 236 & $5.3 \mathrm{E}-05$ & $5 \mathrm{E}-06$ \\
\hline Mass 237 & $5.1 \mathrm{E}-05$ & $3 \mathrm{E}-06$ \\
\hline Mass 238 & $4.61 \mathrm{E}-02$ & $6.8 \mathrm{E}-03$ \\
\hline Mass 239 & $5.4 \mathrm{E}-05$ & $1.7 \mathrm{E}-05$ \\
\hline Mass 240 & $1.5 \mathrm{E}-05$ & $6 \mathrm{E}-06$ \\
\hline Mass 241 & $<7.9 \mathrm{E}-06$ & -- \\
\hline Mass 242 & $1.9 \mathrm{E}-05$ & $1 \mathrm{E}-06$ \\
\hline Mass 243 & $<7.9 \mathrm{E}-06$ & -- \\
\hline Mass 244 & $<7.9 \mathrm{E}-06$ & -- \\
\hline
\end{tabular}


Table 12: Tank 38H filtered Free Liquid ICP-ES results (mg/L)

\begin{tabular}{|c|c|c|}
\hline Tank 38H & \multicolumn{2}{|c|}{ HTF-E-03-114 FL } \\
\hline$(\mathrm{mg} / \mathrm{L})$ & Average & St. Dev. \\
\hline $\mathrm{Ag}$ & $<1.35 E+01$ & -- \\
\hline $\mathrm{Al}$ & $4.30 \mathrm{E}+03$ & $4 \mathrm{E}+01$ \\
\hline$B$ & $<1.46 E+03$ & - \\
\hline $\mathrm{Ba}$ & $<1.35 E+01$ & -- \\
\hline $\mathrm{Ca}$ & $<4.09 E+02$ & - \\
\hline $\mathrm{Cd}$ & $<1.80 E+01$ & - \\
\hline $\mathrm{Ce}$ & $<2.25 E+02$ & - \\
\hline $\mathrm{Cr}$ & $1.33 E+02$ & $1.1 \mathrm{E}+01$ \\
\hline $\mathrm{Cu}$ & $<2.80 E+01$ & -- \\
\hline $\mathrm{Fe}$ & $<1.99 E+01$ & - \\
\hline $\mathrm{Gd}$ & $<2.43 E+01$ & - \\
\hline $\mathrm{K}$ & $<8.59 E+03$ & - \\
\hline La & $<1.80 E+01$ & -- \\
\hline $\mathrm{Li}$ & $<7.68 E+01$ & -- \\
\hline $\mathrm{Mg}$ & $<5.59 E+01$ & - \\
\hline $\mathrm{Mn}$ & $<1.99 E+01$ & - \\
\hline Mo & $<1.84 E+02$ & -- \\
\hline $\mathrm{Na}$ & $2.47 E+05$ & $1 \mathrm{E}+03$ \\
\hline $\mathrm{Ni}$ & $<6.76 E+01$ & -- \\
\hline$P$ & $4.78 \mathrm{E}+02$ & $5 \mathrm{E}+00$ \\
\hline $\mathrm{Pb}$ & $<2.22 E+02$ & - \\
\hline$S$ & $2.26 \mathrm{E}+03$ & $1.4 \mathrm{E}+02$ \\
\hline $\mathrm{Sb}$ & $<1.36 E+02$ & -- \\
\hline $\mathrm{Si}$ & $1.46 \mathrm{E}+02$ & $6 \mathrm{E}+00$ \\
\hline Sn & $<2.22 E+02$ & - \\
\hline $\mathrm{Sr}$ & $<9.02 E+01$ & - \\
\hline $\mathrm{Ti}$ & $<5.42 E+00$ & - \\
\hline $\mathrm{V}$ & $<9.92 E+00$ & -- \\
\hline $\mathrm{Zn}$ & $<4.96 E+01$ & -- \\
\hline $\mathrm{Zr}$ & $<1.08 E+01$ & -- \\
\hline
\end{tabular}


WSRC-TR-2004-00129

Revision 0

Table 13: Tank 38H filtered Free Liquid rad. chem. results (pCi/mL)

\begin{tabular}{|c|rr|}
\hline Tank $38 \mathrm{H}$ & \multicolumn{2}{|c|}{ HTF-E-03-114 FL } \\
\hline$(\mathrm{pCi} / \mathrm{mL})$ & Average & St. Dev. \\
\hline${ }^{90} \mathrm{Sr}^{\mathrm{b}}$ & $6.2 \mathrm{E}+04$ & $6.2 \mathrm{E}+04$ \\
\hline${ }^{137} \mathrm{Cs}$ & $1.93 \mathrm{E}+08$ & $5 \mathrm{E}+06$ \\
\hline${ }^{238} \mathrm{Pu}$ & $5.78 \mathrm{E}+03$ & $1.5 \mathrm{E}+02$ \\
\hline${ }^{239 / 240} \mathrm{Pu}{ }^{\text {a }}$ & $1.0 \mathrm{E}+03$ & $3 \mathrm{E}+02$ \\
\hline${ }^{241} \mathrm{Am}$ & $<9.15 \mathrm{E}+02$ & -- \\
\hline
\end{tabular}

Note a: ${ }^{239 / 240} \mathrm{Pu}$ was detected at the background (sample contamination) level and should be regarded as an upper limit.

Note b: There was a large ${ }^{90} \mathrm{Sr}$ variation measured in replicate samples.

Table 14: Tank 38H filtered Free Liquid ICP-MS results (mg/L)

\begin{tabular}{|c|cc|}
\hline Tank 38H & \multicolumn{2}{|c|}{ HTF-E-03-114 FL } \\
\hline$(\mathrm{mg} / \mathrm{L})$ & Average & St. Dev. \\
\hline Mass 59 & $<9.3 \mathrm{E}-02$ & -- \\
\hline Mass 88 & \multicolumn{3}{|c|}{$6.7 \mathrm{E}-02$} & $5.1 \mathrm{E}-02$ \\
\hline Mass 99 & $2.93 \mathrm{E}+00$ & $4 \mathrm{E}-02$ \\
\hline Mass 101 & $3.2 \mathrm{E}-01$ & $4 \mathrm{E}-02$ \\
\hline Mass 133 & $5.54 \mathrm{E}+00$ & $4 \mathrm{E}-02$ \\
\hline Mass 135 & $6.1 \mathrm{E}-01$ & $2 \mathrm{E}-02$ \\
\hline Mass 137 & $2.02 \mathrm{E}+00$ & $4 \mathrm{E}-02$ \\
\hline Mass 138 & $<=1.1 \mathrm{E}-01$ & $8 \mathrm{E}-02$ \\
\hline Mass 230 & $<1.5 \mathrm{E}-01$ & -- \\
\hline Mass 231 & $<1.5 \mathrm{E}-01$ & -- \\
\hline Mass 232 & $<1.5 \mathrm{E}-01$ & -- \\
\hline Mass 233 & $<1.5 \mathrm{E}-01$ & -- \\
\hline Mass 234 & $<1.5 \mathrm{E}-01$ & -- \\
\hline Mass 235 & \multicolumn{3}{|c|}{$1.7 \mathrm{E}-01$} & $2 \mathrm{E}-02$ \\
\hline Mass 236 & $<1.5 \mathrm{E}-01$ & -- \\
\hline Mass 237 & $<1.5 \mathrm{E}-01$ & -- \\
\hline Mass 238 & $1.26 \mathrm{E}+01$ & $6 \mathrm{E}-01$ \\
\hline Mass 239 & $<1.5 \mathrm{E}-01$ & -- \\
\hline Mass 240 & $<1.5 \mathrm{E}-01$ & -- \\
\hline Mass 241 & $<1.5 \mathrm{E}-01$ & -- \\
\hline Mass 242 & $<1.5 \mathrm{E}-01$ & -- \\
\hline Mass 243 & $<1.5 \mathrm{E}-01$ & -- \\
\hline Mass 244 & $<1.5 \mathrm{E}-01$ & -- \\
\hline
\end{tabular}


Table 15: Tank 38H filtered Free Liquid IC anions results (mg/L)

\begin{tabular}{|c|c|c|}
\hline Tank 38H & \multicolumn{2}{|c|}{ HTF-E-03-114 FL } \\
\hline$(\mathrm{mg} / \mathrm{L})$ & Average & St. Dev. \\
\hline $\mathrm{NO}_{3}^{-}$ & $1.29 \mathrm{E}+05$ & $2 \mathrm{E}+03$ \\
\hline $\mathrm{NO}_{2}^{-}$ & $8.13 E+04$ & $1.6 \mathrm{E}+03$ \\
\hline $\mathrm{SO}_{4}{ }^{2-}$ & $2.27 \mathrm{E}+03$ & $0 \mathrm{E}+00$ \\
\hline $\mathrm{PO}_{4}{ }^{3-}$ & $1.13 E+03$ & $0 \mathrm{E}+00$ \\
\hline $\mathrm{Cl}^{-}$ & $</=1.75 \mathrm{E}+02$ & $0 \mathrm{E}+00$ \\
\hline $\mathrm{F}^{-}$ & $<1.75 E+02$ & -- \\
\hline $\mathrm{C}_{2} \mathrm{O}_{4}{ }^{2-}$ & $<8.73 E+02$ & - \\
\hline $\mathrm{CHO}_{2}^{-}$ & $2.14 \mathrm{E}+03$ & $1.9 \mathrm{E}+02$ \\
\hline Total Base (M) & $6.66 \mathrm{E}+00$ & $8 \mathrm{E}-02$ \\
\hline Free $\mathrm{OH}^{-}$ & $9.43 E+04$ & $2.7 \mathrm{E}+03$ \\
\hline $\mathrm{CO}_{3}{ }^{2-}(\mathrm{TIC})$ & $1.72 \mathrm{E}+04$ & $1.18 \mathrm{E}+04$ \\
\hline TOC & $4.8 E+03$ & $2.8 \mathrm{E}+03$ \\
\hline
\end{tabular}

Table 16: Likely major components of Tank $38 \mathrm{H}$ salt solids, normalized to $100 \mathrm{wt} \%$

\begin{tabular}{|l|c|}
\hline & (wt \%) \\
\hline $\mathrm{NaNO}_{3}$ & 85.0 \\
\hline $\mathrm{Na}_{2} \mathrm{CO}_{3}{ }^{*} \mathrm{H}_{2} \mathrm{O}$ & 10.2 \\
\hline $\mathrm{Na}_{2} \mathrm{SO}_{4}$ & 3.7 \\
\hline $\mathrm{Na}_{2} \mathrm{C}_{2} \mathrm{O}_{4}$ & 1.1 \\
\hline $\mathrm{NaAlO}_{2}{ }^{*} 2 \mathrm{H}_{2} \mathrm{O}$ & 0.8 \\
\hline $\mathrm{NaF}$ & 0.1 \\
\hline
\end{tabular}



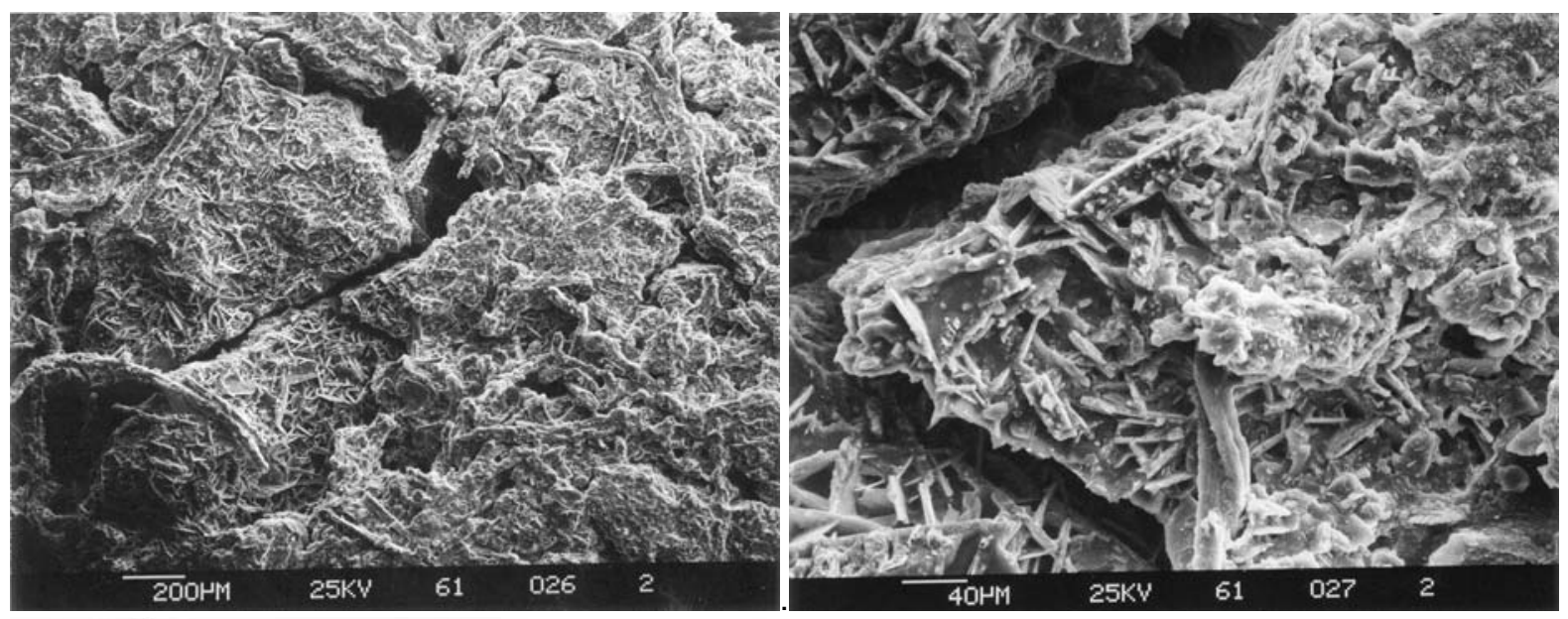

$\mathbb{l}$
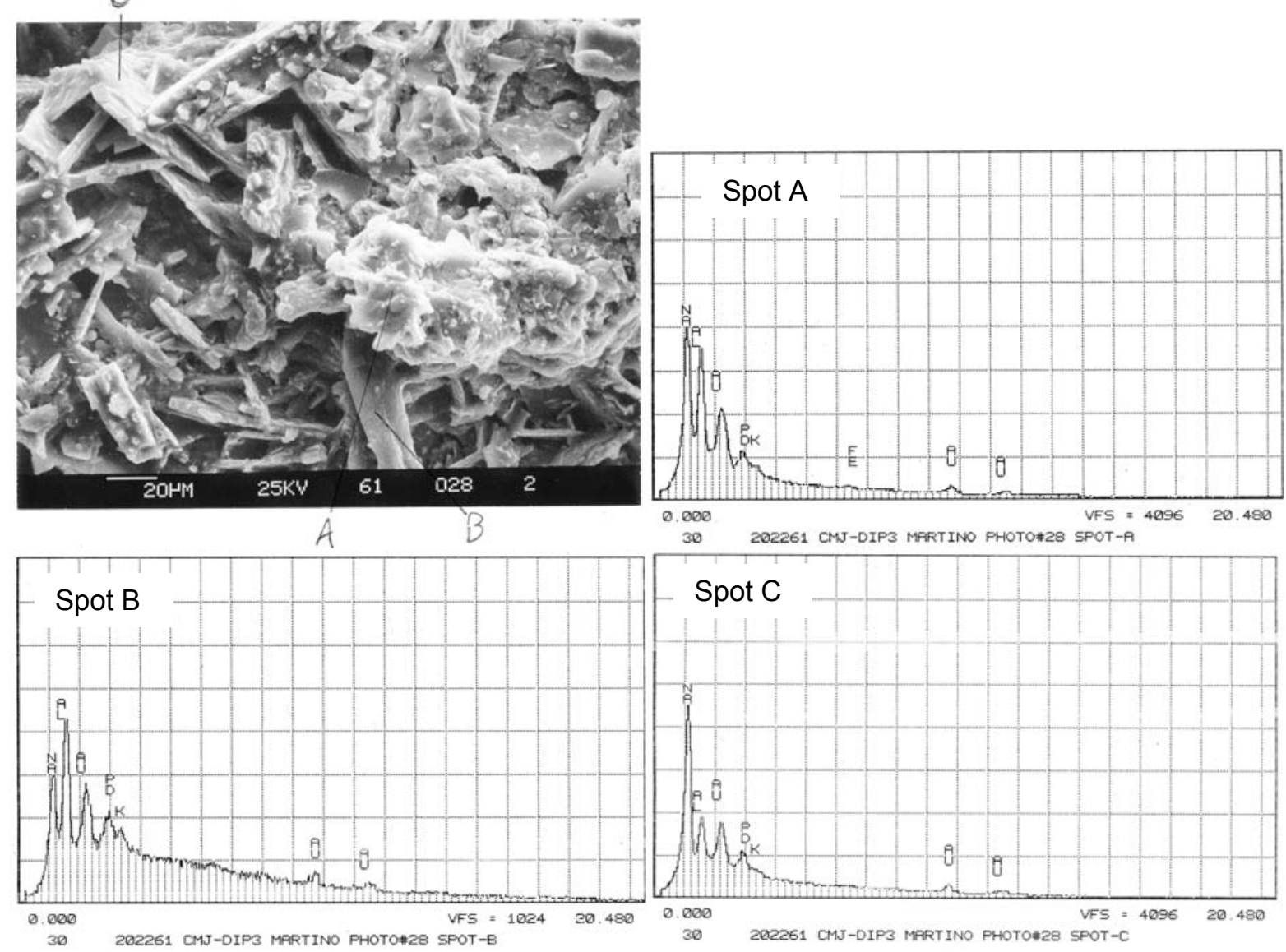

30 202261 CMN-DIP3 MARTINO PHOTO\#28 SPOT-A

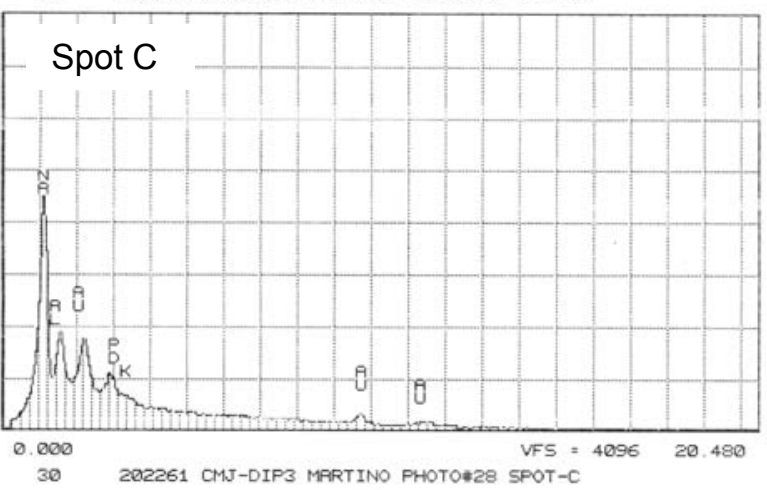

Figure 10: SEM and EDS of needle-like insoluble solids from the filtered free liquid of sample HTF-E-03-114 

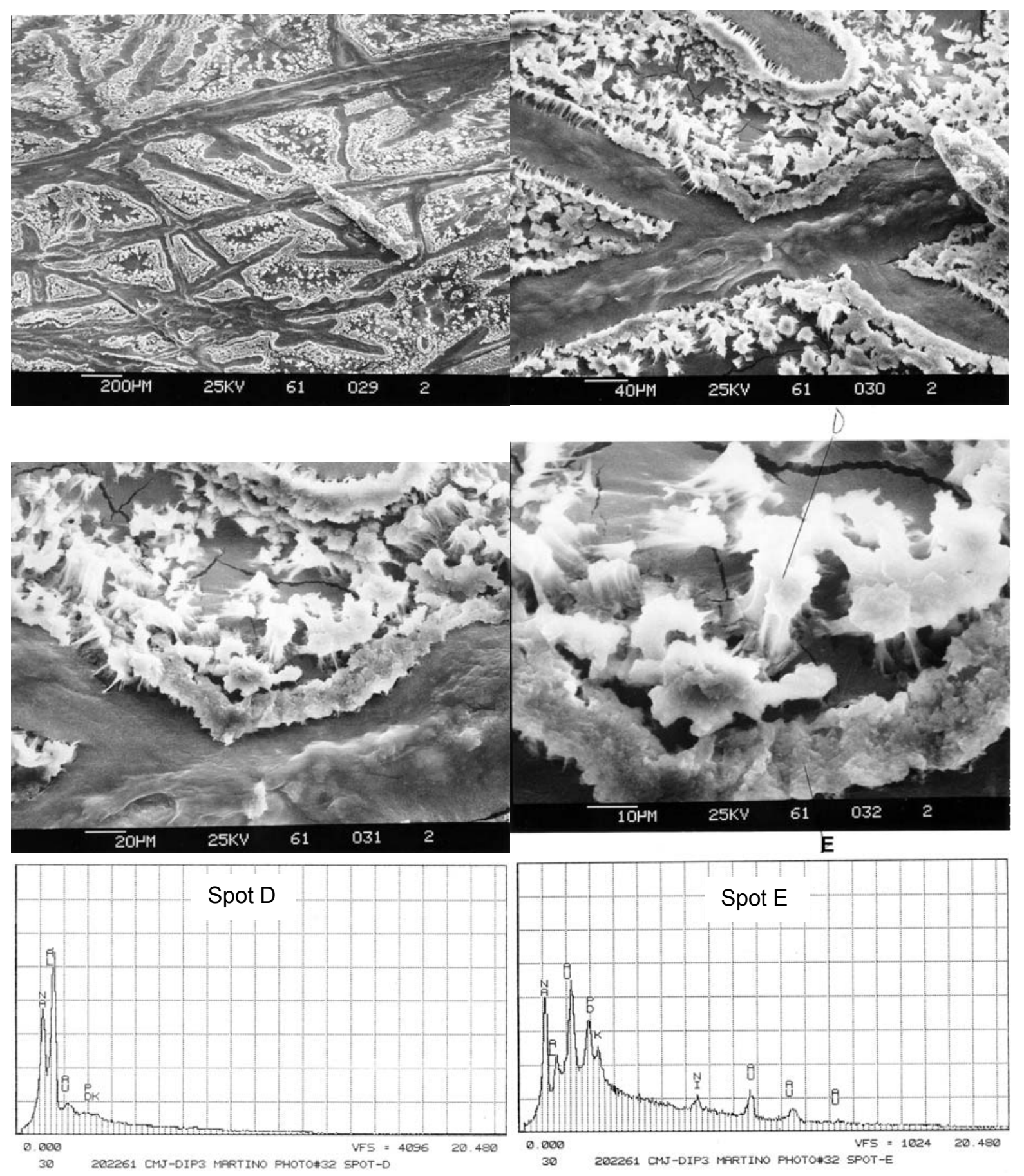

Figure 11: SEM and EDS of insoluble solids from the filtered free liquid of sample HTF-E-03114 

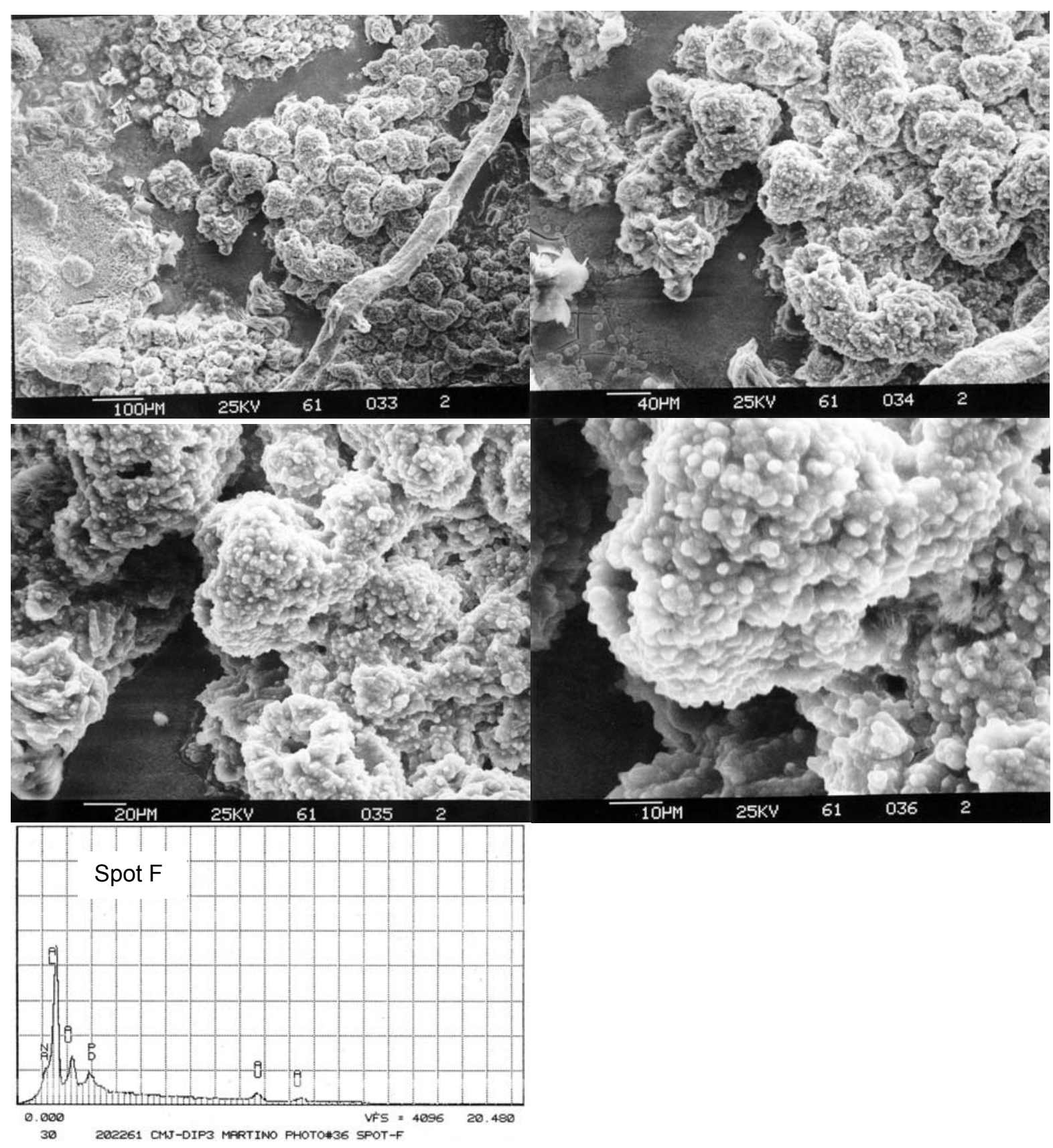

Figure 12: SEM and EDS of globular porous insoluble solids from the filtered free liquid of sample HTF-E-03-114 
Table 17: Tank 38H supernate sample (HTF-E-03-122 and 123) rad. chem. results (pCi/mL)

\begin{tabular}{|c|c|c|c|c|}
\hline Tank $38 \mathrm{H}$ & \multicolumn{2}{|c|}{ As Received } & \multicolumn{2}{|c|}{$0.45-\mu \mathrm{m}$ Filtrate } \\
\hline$(p C i / m L)$ & Average & St. Dev. & Average & St. Dev. \\
\hline${ }^{14} \mathrm{C}$ & -- & & $<1.22 E+03$ & -- \\
\hline${ }^{90} \mathrm{Sr}$ & $2.95 E+04$ & $5.0 \mathrm{E}+03$ & $1.47 \mathrm{E}+04$ & $1.3 E+03$ \\
\hline${ }^{137} \mathrm{Cs}$ & $1.73 E+08$ & $5 E+05$ & $1.70 \mathrm{E}+08$ & $4 \mathrm{E}+06$ \\
\hline${ }^{238} \mathrm{Pu}$ & $2.19 \mathrm{E}+04$ & $1.0 \mathrm{E}+03$ & $2.30 \mathrm{E}+04$ & $1.1 \mathrm{E}+03$ \\
\hline${ }^{239 / 240} \mathrm{Pu}$ & $1.38 E+03$ & $1.7 E+02$ & $1.53 E+03$ & $1.5 \mathrm{E}+02$ \\
\hline
\end{tabular}

Table 18: Tank 38H supernate sample (HTF-E-03-122 and 123) IC anions, wet chemistry titration, and $\mathrm{TIC} / \mathrm{TOC}$ results $(\mathrm{mg} / \mathrm{L})$

\begin{tabular}{|c|lr|}
\hline Tank 38H & \multicolumn{2}{|c|}{$0.45-\mu \mathrm{m}$ Filtrate } \\
\hline$(\mathrm{mg} / \mathrm{L})$ & Average & St. Dev. \\
\hline $\mathrm{NO}_{3}{ }^{-}$ & $1.37 \mathrm{E}+05$ & $1 \mathrm{E}+03$ \\
\hline $\mathrm{NO}_{2}{ }^{-}$ & $8.28 \mathrm{E}+04$ & $5 \mathrm{E}+02$ \\
\hline $\mathrm{SO}_{4}{ }^{2-}$ & $1.69 \mathrm{E}+03$ & $0 \mathrm{E}+00$ \\
\hline $\mathrm{PO}_{4}{ }^{3-}$ & $1.13 \mathrm{E}+03$ & $0 \mathrm{E}+00$ \\
\hline $\mathrm{Cl}^{-}$ & $1.41 \mathrm{E}+02$ & $0 \mathrm{E}+00$ \\
\hline $\mathrm{F}^{-}$ & $7.05 \mathrm{E}+01$ & $0 \mathrm{E}+00$ \\
\hline $\mathrm{C}_{2} \mathrm{O}_{4}{ }^{2-}$ & $2.11 \mathrm{E}+02$ & $0 \mathrm{E}+00$ \\
\hline $\mathrm{CHO}_{2}{ }^{-}$ & $2.11 \mathrm{E}+03$ & $0 \mathrm{E}+00$ \\
\hline $\mathrm{Total} \mathrm{Base}^{(\mathrm{M})}$ & $6.95 \mathrm{E}+00$ & $2.4 \mathrm{E}-01$ \\
\hline $\mathrm{Free} \mathrm{OH}^{-}$ & $8.55 \mathrm{E}+04$ & $3.6 \mathrm{E}+03$ \\
\hline $\mathrm{CO}_{3}{ }^{2-}(\mathrm{TIC})$ & $1.50 \mathrm{E}+04$ & $5.9 \mathrm{E}+03$ \\
\hline TOC & $4.75 \mathrm{E}+03$ & $1.5 \mathrm{E}+03$ \\
\hline $\mathrm{OH}^{-}$(calculated) & $1.11 \mathrm{E}+05$ & \\
\hline
\end{tabular}


WSRC-TR-2004-00129

Revision 0

Table 19: Tank 38H supernate sample (HTF-E-03-122 and 123) ICP-ES results (mg/L)

\begin{tabular}{|c|c|c|c|c|}
\hline \multirow{2}{*}{$\begin{array}{c}\text { Tank 38H } \\
(\mathrm{mg} / \mathrm{L})\end{array}$} & \multicolumn{2}{|c|}{ As Received } & \multicolumn{2}{|c|}{$0.45-\mu \mathrm{m}$ Filtrate } \\
\hline & Average & St. Dev. & Average & St. Dev. \\
\hline $\mathrm{Ag}$ & $<1.06 E+01$ & -- & $<1.03 E+01$ & -- \\
\hline $\mathrm{Al}$ & $2.73 \mathrm{E}+03$ & $1.4 \mathrm{E}+03$ & $4.45 \mathrm{E}+03$ & $1.4 \mathrm{E}+02$ \\
\hline B & $<1.14 E+03$ & -- & $<1.11 E+03$ & -- \\
\hline $\mathrm{Ba}$ & $<1.06 E+01$ & -- & $<1.03 E+01$ & -- \\
\hline $\mathrm{Ca}$ & $<3.20 E+02$ & -- & $<3.12 E+02$ & -- \\
\hline $\mathrm{Cd}$ & $<1.41 E+01$ & - & $<1.37 E+01$ & -- \\
\hline $\mathrm{Ce}$ & $<1.75 E+02$ & -- & $<1.71 E+02$ & -- \\
\hline $\mathrm{Cr}$ & $1.19 \mathrm{E}+02$ & $3.6 \mathrm{E}+01$ & $1.46 \mathrm{E}+02$ & $3 E+00$ \\
\hline $\mathrm{Cu}$ & $<2.19 E+01$ & -- & $<2.13 E+01$ & -- \\
\hline $\mathrm{Fe}$ & $9.76 \mathrm{E}+01$ & $4.47 \mathrm{E}+01$ & $2.52 \mathrm{E}+01$ & $3.11 \mathrm{E}+01$ \\
\hline $\mathrm{Gd}$ & $<1.90 E+01$ & -- & $<1.86 E+01$ & -- \\
\hline $\mathrm{K}$ & $<6.73 E+03$ & -- & $<6.55 E+03$ & -- \\
\hline $\mathrm{La}$ & $<1.41 E+01$ & -- & $<1.37 E+01$ & -- \\
\hline $\mathrm{Li}$ & $<6.00 E+01$ & -- & $</=5.92 E+01$ & $1.0 \mathrm{E}+00$ \\
\hline $\mathrm{Mg}$ & $<4.38 E+01$ & -- & $<4.26 E+01$ & -- \\
\hline $\mathrm{Mn}$ & $<1.55 E+01$ & -- & $<1.51 E+01$ & -- \\
\hline Mo & $<1.44 E+02$ & -- & $<1.40 E+02$ & -- \\
\hline $\mathrm{Na}$ & $2.40 \mathrm{E}+05$ & $3 E+03$ & $2.42 \mathrm{E}+05$ & $2 E+03$ \\
\hline $\mathrm{Ni}$ & $<5.29 E+01$ & -- & $<5.16 E+01$ & -- \\
\hline$P$ & $4.41 \mathrm{E}+02$ & $4.9 \mathrm{E}+01$ & $4.16 \mathrm{E}+02$ & $1.0 \mathrm{E}+01$ \\
\hline $\mathrm{Pb}$ & $<1.74 E+02$ & -- & $<1.70 E+02$ & -- \\
\hline$S$ & $1.53 \mathrm{E}+03$ & $3 E+01$ & $1.66 \mathrm{E}+03$ & $7 E+01$ \\
\hline $\mathrm{Sb}$ & $<1.07 E+02$ & -- & $<1.04 E+02$ & -- \\
\hline $\mathrm{Si}$ & $8.74 \mathrm{E}+02$ & $1.93 E+02$ & $7.03 E+02$ & $1.5 \mathrm{E}+01$ \\
\hline Sn & $<1.73 E+02$ & -- & $<1.68 E+02$ & -- \\
\hline $\mathrm{Sr}$ & $<7.06 E+01$ & -- & $<6.87 E+01$ & -- \\
\hline $\mathrm{Ti}$ & $<4.23 E+00$ & -- & $<4.12 E+00$ & -- \\
\hline $\mathrm{V}$ & $<7.77 E+00$ & -- & $<7.57 E+00$ & -- \\
\hline $\mathrm{Zn}$ & $<3.89 E+01$ & -- & $<3.78 E+01$ & -- \\
\hline $\mathrm{Zr}$ & $<8.47 E+00$ & -- & $<8.25 E+00$ & -- \\
\hline
\end{tabular}


Table 20: Tank 38H supernate sample (HTF-E-03-122 and 123) ICP-MS results (mg/L)

\begin{tabular}{|c|cc|c|c|}
\hline Tank 38H & \multicolumn{2}{|c|}{ As Received } & \multicolumn{2}{c|}{$0.45-\mu \mathrm{m}$ Filtrate } \\
\hline$(\mathrm{mg} / \mathrm{L})$ & Average & St. Dev. & Average & St. Dev. \\
\hline Mass 59 & $<5.9 E-01$ & -- & $<5.7 E-01$ & -- \\
\hline Mass 88 & $<7.9 E-02$ & -- & $<7.7 E-02$ & -- \\
\hline Mass 99 & $2.94 \mathrm{E}+00$ & $2.8 \mathrm{E}-01$ & $2.93 \mathrm{E}+00$ & $9.7 \mathrm{E}-02$ \\
\hline Mass 101 & $3.7 \mathrm{E}-01$ & $2 \mathrm{E}-02$ & $4.3 \mathrm{E}-01$ & $9 \mathrm{E}-03$ \\
\hline Mass 133 & $3.66 \mathrm{E}+00$ & $1.7 \mathrm{E}-01$ & $3.78 \mathrm{E}+00$ & $2.3 \mathrm{E}-01$ \\
\hline Mass 135 & $6.6 \mathrm{E}-01$ & $5 \mathrm{E}-02$ & $6.4 \mathrm{E}-01$ & $5 \mathrm{E}-02$ \\
\hline Mass 137 & $1.96 \mathrm{E}+00$ & $7 \mathrm{E}-02$ & $1.99 \mathrm{E}+00$ & $9 \mathrm{E}-03$ \\
\hline Mass 138 & $2.8 \mathrm{E}-01$ & $2 \mathrm{E}-02$ & $3.2 \mathrm{E}-01$ & $8 \mathrm{E}-02$ \\
\hline Mass 230 & $<7.3 \mathrm{E}-02$ & -- & $<7.1 E-02$ & -- \\
\hline Mass 231 & $<7.3 E-02$ & -- & $<7.1 E-02$ & -- \\
\hline Mass 232 & $<7.3 E-02$ & -- & $<7.1 E-02$ & -- \\
\hline Mass 233 & $<7.3 E-02$ & -- & $<7.1 E-02$ & -- \\
\hline Mass 234 & $<7.3 E-02$ & -- & $<7.1 E-02$ & -- \\
\hline Mass 235 & $2.12 \mathrm{E}-01$ & $5.0 \mathrm{E}-02$ & $1.78 \mathrm{E}-01$ & $6 \mathrm{E}-03$ \\
\hline Mass 236 & $<7.3 E-02$ & -- & $<7.1 E-02$ & -- \\
\hline Mass 237 & $<7.3 E-02$ & -- & $<7.1 E-02$ & -- \\
\hline Mass 238 & $4.05 \mathrm{E}+01$ & $4 \mathrm{E}-01$ & $4.01 \mathrm{E}+01$ & $4 \mathrm{E}-01$ \\
\hline Mass 239 & $<7.3 E-02$ & -- & $<7.1 E-02$ & -- \\
\hline Mass 240 & $<7.3 E-02$ & -- & $<7.1 E-02$ & -- \\
\hline Mass 241 & $<7.3 E-02$ & -- & $<7.1 E-02$ & -- \\
\hline Mass 242 & $<7.3 E-02$ & -- & $<7.1 E-02$ & -- \\
\hline Mass 243 & $<7.3 E-02$ & -- & $<7.1 E-02$ & -- \\
\hline Mass 244 & $<7.3 E-02$ & -- & $<7.1 E-02$ & -- \\
\hline
\end{tabular}

Table 21: Tank 38H supernate sample (HTF-E-03-122 and 123) AA results (mg/L)

\begin{tabular}{|c|rc|rc|}
\hline Tank 38H & \multicolumn{2}{|c|}{ As Received } & \multicolumn{2}{c|}{$0.45-\mu \mathrm{m}$ Filtrate } \\
\hline (mg/L) & Average & St. Dev. & Average & St. Dev. \\
\hline As & $<3.5 E+00$ & -- & $<3.4 E+00$ & -- \\
\hline $\mathrm{K}$ & $9.6 \mathrm{E}+02$ & $8 \mathrm{E}+00$ & $9.4 \mathrm{E}+02$ & $1 \mathrm{E}+01$ \\
\hline $\mathrm{Se}$ & $<3.5 E+00$ & -- & $<3.4 E+00$ & -- \\
\hline $\mathrm{Hg}$ & $4.5 \mathrm{E}+01$ & $3 \mathrm{E}-01$ & $5.1 \mathrm{E}+01$ & $3 \mathrm{E}+00$ \\
\hline
\end{tabular}

